\title{
Deal or No Deal: Why Courts Should Allow Defendants to Present Evidence that They Rejected Favorable Plea Bargains
}

\section{Colin Miller}

\section{INTRODUCTION}

Robert Woodsum is charged with two counts of felonious sexual assault and faces up to fourteen years incarceration if found guilty of both counts. ${ }^{1}$ Woodsum enters into plea negotiations with the prosecutor, who offers a deal under which Woodsum would plead guilty to two misdemeanor charges of simple assault in exchange for the prosecutor recommending to the judge that Woodsum receive a two year sentence that would be deferred, contingent on Woodsum's good behavior and pursuit of counseling. ${ }^{2}$ Woodsum, however, rejects this plea bargain, which the State later characterizes as "extraordinarily beneficial" to Woodsum. ${ }^{3}$ When his case proceeds to trial, Woodsum seeks to admit evidence that he turned down this plea bargain, claiming that his rejection of such an "extraordinarily beneficial" deal and willingness to risk fourteen years incarceration is evidence of his consciousness of innocence. ${ }^{4}$ The trial court rebuffs his attempt, and Woodsum is convicted of both counts. ${ }^{5}$

Woodsum's ensuing appeal eventually reaches the Supreme Court of New Hampshire in State v. Woodsum. ${ }^{6}$ One of Woodsum's arguments is that evidence of the prosecutor's offer and his rejection is not precluded under New Hampshire Rule of Evidence 410, ${ }^{7}$ which, like Federal Rule

* Visiting Associate Professor, William and Mary School of Law; Associate Professor, The John Marshall Law School; Blog Editor, EVIDENCEPROF BLOG, http://lawprofessors. typepad.com/evidenceprof/. I would like to thank my wife Zoe for her support and assistance in the writing of this Article.

1. State v. Woodsum, 624 A.2d 1342, 1342-43 (N.H. 1993).

2. Id. at 1343.

3. Id. at $1342-43$.

4. Id. at 1343 .

5. Id. at $1342-43$.

6. Id. at 1342 .

7. Id. at 1343 . 
of Evidence 410, merely deems inadmissible statements made during plea discussions when offered "against the defendant who made the plea or was a participant in the plea discussions." argument that his rejection of the plea deal evinces his innocent state of mind, and he claims that the State can avoid the admission of such evidence in the future by having defendants "sign waivers of any right to introduce rejected, highly beneficial plea offers as evidence." "The State counters that, if the court accepted Woodsum's argument, "competent prosecutors will simply require such waivers in all cases, thus adding a new layer of paperwork to the process and undoubtedly expanding pretrial litigation whenever such a waiver was not obtained."10

The Supreme Court of New Hampshire affirms, finding, inter alia, that Rule 410 does not provide "express authority for the admission of the rejection of a plea offer." 11 Furthermore, the court finds that "[m]any inferences follow from a defendant's decision to exercise his or her right to a jury trial, rather than to accept a plea offer," but it only lists two: (1) The defendant prefers the possibility of acquittal to the certainty of punishment after a guilty plea, or (2) the defendant truly believes that he did not commit the crime charged. ${ }^{12}$ The court seems to find the first option more likely, concluding that "[a]n 'extraordinarily beneficial' plea offer is especially likely to induce a defendant to risk a trial, regardless of his or her guilt or innocence, for the offer of a beneficial plea may indicate that there are problems with the State's case."13

The court does give the second option some credence, noting that "[i]t is also plausible to infer from the rejection of a beneficial plea offer ... that a defendant believes he or she did not commit the crime."14 But according to the court, "[t]his belief is ... only marginally relevant to the issues in any criminal trial.", 15 Furthermore, "[s]et against the marginal relevance ... is the great likelihood that its admission will draw extraneous, misleading information into a criminal trial .... [And this] inevitably invites an exploration of such collateral matters as the

8. N.H. R. EVID. 410 (emphasis added); see also FED. R. EVID. 410 (same language).

9. Woodsum, $624 \mathrm{~A} .2 \mathrm{~d}$ at 1344.

10. Id.

11. Id. at 1343 .

12. Id. at 1344 .

13. Id.

14. Id.

15. Id. 
prosecutor's reasons for making the offer ... or the defendant's motives for rejecting it."16

Any other court in this country almost certainly would have reached the same conclusion. In its 1991 opinion in State v. Pearson, the Court of Appeals of Utah precluded a defendant from presenting evidence that he rejected a favorable plea bargain, in the process noting that it had "found no appellate decisions which have reached a contrary result, given the narrow issue before us." ${ }^{17}$ Moreover, no court since 1991 appears to have reached a contrary conclusion. ${ }^{18}$ Courts thus have categorically concluded that although Federal Rule of Evidence 410 and state counterparts merely provide that statements made during plea discussions are inadmissible "against the defendant," such statements are also inadmissible "against the prosecution."

In reality, however, a criminal defendant who wants to enter into plea discussions with the prosecution can rarely prevent the prosecution from admitting his incriminatory statements made during such discussions as substantive evidence of his guilt at trial if a plea deal is not reached. As an example, consider the case of Roger Rebbe. Roger Rebbe, an accountant, was suspected of preparing false tax returns. ${ }^{19} \mathrm{He}$ and his attorney met with government agents, who informed them that they would not engage in plea discussions unless they both signed a waiver. $^{20}$ That waiver provided that if the sides did not reach a plea agreement, "the government may use... statements made by you or your client at the meeting and all evidence obtained directly or indirectly from those statements for the purposes of cross-examination should your client testify, or to rebut any evidence, argument or representations offered by or on behalf of your client in connection with the trial.,21 Rebbe and his attorney signed the waiver, Rebbe made incriminatory statements—namely, "proffer statements"-during plea discussions, and the discussions did not result in a plea agreement. ${ }^{22}$ The government subsequently informed Rebbe of its intent to introduce his incriminatory statements at trial consistent with the terms of the waiver. ${ }^{23}$ Rebbe

16. Id.

17. 818 P.2d 581, 583 n.5 (Utah Ct. App. 1991).

18. See infra notes 99-113 and accompanying text. Most recently, in July 2010, the Sixth Circuit found no error in the district court's exclusion of such evidence in United States v. Geisen, 612 F.3d 471, 475 (6th Cir. 2010).

19. United States v. Rebbe, 314 F.3d 402, 404 (9th Cir. 2002).

20. See id.

21. Id.

22. Id.

23. Id. 
moved to exclude those statements, but the district court denied his motion, finding that his statements would be "admissible to rebut any evidence or arguments he made at trial that were inconsistent with his proffer statements." 24

After the government rested its case, Rebbe requested an advisory opinion "as to whether the admissibility of [his] proffer statements had been triggered." 25 The district court refused to rule on the issue, and Rebbe decided to hedge his bets by presenting four defense witnesses but not testifying on his own behalf. ${ }^{26}$ The gamble, though, did not pay off; instead, at the close of the defendant's case, the government successfully moved for the admission of Rebbe's statements as substantive evidence of Rebbe's guilt. ${ }^{27}$ On Rebbe's ensuing appeal, in United States $v$. Rebbe, the Ninth Circuit affirmed, concluding that Rebbe presented a defense that was inconsistent with his proffer statements by having his attorney elicit certain testimony from defense witnesses during direct examination and prosecution witnesses during cross-examination. ${ }^{28}$

In reaching this conclusion, the Ninth Circuit relied upon the opinion of the United States Supreme Court in United States v. Mezzanatto. ${ }^{29}$ In Mezzanatto, the Supreme Court found that a prosecutor can force a criminal defendant to waive the protections of Federal Rule of Evidence 410 and its counterpart, Federal Rule of Criminal Procedure 11(e)(6), by having him sign a waiver indicating that if a plea deal is not reached and the defendant testifies at trial, the prosecutor can impeach him with his contradictory statements made during plea discussions-an impeachment waiver. $^{30}$ To reach this result, the Court rejected the defendant's argument that Rules 410 and 11(e)(6) should not be waiveable because it would discourage defendants from engaging in plea negotiations, finding that "[a] sounder way to encourage settlement is to permit the interested parties to enter into knowing and voluntary negotiations without any arbitrary limits on their bargaining chips."

\footnotetext{
24. Id. at 404-05.

25. Id. at 405 .

26. Id.

27. Id.

28. Id. at 406-09.

29. 513 U.S. 196 (1995).

30. Id. at 205-10; see also United States v. Sylvester, 583 F.3d 285, 291 (5th Cir. 2009) (noting that "Mezzanatto, for its part, explained that impeachment waivers do not undermine these efforts ..." of encouraging candor in plea bargaining).

31. Mezzanatto, 513 U.S. at 208.
} 
The Court in Mezzanatto did not answer the question addressed in Rebbe: Can the prosecution force a criminal defendant to waive the protections of Rule 410 by having him sign a waiver indicating that if a plea deal is not reached, the prosecutor can substantively use his statements made during plea discussions if they contradict any evidence, arguments or representations offered by or on his behalf? ${ }^{32}$ That said, every court addressing a challenge to a waiver like the waiver in Rebbe-a rebuttal waiver ${ }^{33}$ - has relied upon the analysis in Mezzanatto to find the waiver constitutional. ${ }^{34}$ Moreover, each of the three federal appellate courts that have addressed the constitutionality of a waiver allowing the prosecution to use a defendant's statements made during plea discussions substantively as part of its case-in-chief-a case-in-chief waiver-has relied upon Mezzanatto to reach the same result. ${ }^{35}$

This Article addresses the question of whether courts can consistently allow prosecutors to present defendants' incriminatory statements made during plea discussions while precluding those same defendants from presenting evidence that they rejected favorable plea bargains. It concludes that courts cannot prevent defendants from presenting evidence that they rejected favorable plea bargains based upon Mezzanatto and that none of the arguments against admissibility hold water.

Part II of this Article details the creation and amendment of Federal Rule of Evidence 410 and Federal Rule of Criminal Procedure 11(e)(6). It pays particular attention to the 1979 amendment to the Rules, which made clear that defendants are not precluded from introducing into evidence exculpatory statements made during plea discussions. Part III focuses upon opinions dealing with evidence of rejected plea bargains and the various and sundry reasons given by courts for excluding them. As a counterpoint, it notes that courts consistently have found that defendants can present evidence that they rejected prosecutorial offers of immunity but have refused to extend this logic to evidence of rejected plea bargains. Part IV deals with Mezzanatto and the way in which its progeny has extended its reasoning regarding impeachment waivers to allow for rebuttal and case-in-chief waivers. Finally, Part V argues that

32. See Rebbe, 314 F.3d at 406 .

33. See Sylvester, 583 F.3d at 291 ("At least four circuits, including the Second, Third, Seventh, and Ninth, already countenance rebuttal waivers, allowing use of a defendant's plea statements if the defendant presents any evidence at trial that contradicts his plea statements.”).

34. See infra note 182 and accompanying text.

35. See, e.g., Sylvester, 583 F.3d at 289-91 (joining the Eighth and D.C. Circuits in upholding case-in-chief waivers by extending the Mezzanatto analysis). 
the Supreme Court's logic in Mezzanatto compels the conclusion that evidence that defendants rejected favorable plea bargains should be admissible and that no rule of evidence precludes its admission.

\section{The Passage And Amendment of Federal Rule of EVIDENCE 410 AND FEdERAL Rule OF Civil PRocedure 11(E)(6)}

\section{A. The Passage of Rules 410 and 11(e)(6)}

The Federal Rules of Criminal Procedure did not have any explicit provision governing the admissibility of statements made during plea bargaining when Congress enacted the Rules in $1946 .{ }^{36}$ In 1975, Congress finally created Federal Rule of Criminal Procedure 11(e)(6), as well as the identical Federal Rule of Evidence $410 .^{37}$ Both of these rules codified common law precedent, which held that withdrawn guilty pleas, pleas of nolo contendere, and offers to plead guilty and nolo contendere were inadmissible against an accused. ${ }^{38}$ The Advisory Committee's Note to Rule 410 indicates that the purpose of the Rule was "the promotion of disposition of criminal cases by compromise.” ${ }^{\text {,9 }}$ As enacted, Rule 410 and Rule 11(e)(6) stated in relevant part:

[E]vidence of a plea of guilty, later withdrawn, or a plea of nolo contendere, or of an offer to plead guilty or nolo contendere to the crime charged or any other crime, or of statements made in connection with, and relevant to, any of the foregoing pleas or offers, is not admissible in any civil or criminal proceeding against the person who made the plea or offer.

\section{B. The 1979 Amendment to Rules 410 and 11(e)(6)}

In 1979, Congress amended these Rules with the primary purpose of clarifying exactly what evidence relating to plea bargaining they render

\footnotetext{
36. Colin Miller, The Best Offense Is a Good Defense: Why Criminal Defendants' Nolo Contendere Pleas Should Be Inadmissible Against Them When They Become Civil Plaintiffs, 75 U. CIN. L. REV. 725, 730 (2006).

37. Id.

38. See FED. R. EvID. 410 advisory committee's note (construing cases such as Gen. Elec. Co. v. City of San Antonio, 334 F.2d 480 (5th Cir. 1964) and Kercheval v. United States, 274 U.S. 220 (1927)).

39. Id.

40. United States v. Brooks, 536 F.2d 1137, 1138 (6th Cir. 1976) (quoting FED. R. CRIM. P. 11(e)(6) (1975)), superseded by FED. R. CRIM. P. 11(e)(6) (1979 amendment).
} 
inadmissible. ${ }^{41}$ Specifically, the main purpose of these amendments was to clarify the term "against" in both Rules. The Advisory Committee gave the following description of the amendments:

The phrase "in any civil or criminal proceeding" has been moved from its present position, following the word "against," for purposes of clarity. An ambiguity presently exists because the word "against" may be read as referring either to the kind of proceeding in which the evidence is offered or the purpose for which it is offered. The change makes it clear that the latter construction is correct. ${ }^{42}$

In other words, there were two possible constructions of the preamendment Rules, which deemed inadmissible certain pleas and plearelated statements "in any civil or criminal proceeding against the person who made the plea or offer." 43 Under the first construction, these Rules rendered certain pleas and plea-related statements inadmissible in a certain kind of proceeding: a proceeding against the defendant making the plea or plea-related statement. ${ }^{44}$ Under this construction, if a defendant were charged with murder, any exculpatory or incriminatory statements made by the defendant or the prosecutor during plea discussions would be inadmissible at the defendant's subsequent criminal trial or in a civil wrongful death action against him.

Under the second construction, these Rules rendered certain pleas and plea-related statements inadmissible when offered for a certain purpose: when offered against the defendant. ${ }^{45}$ Under this construction, if a defendant were charged with arson, any incriminatory statements made by the defendant during plea discussions would be inadmissible against the defendant, whether at the defendant's subsequent criminal trial, a civil action against the defendant, or a later civil action brought by the defendant as a civil plaintiff, such as an action against an insurance company refusing to pay for the fire damage caused by the alleged arson. $^{46}$ Conversely, under this construction, these Rules would not render inadmissible otherwise admissible exculpatory statements made by the defendant or prosecutor during plea discussions in any type of

\footnotetext{
41. Miller, supra note 36, at 731-32.

42. FED. R. CRIM. P. 11 advisory committee's note.

43. Id.

44. Id.

45. Id.

46. Miller, supra note 36, at 732-33.
} 
action because they would be admitted on behalf of the defendant, not against him. ${ }^{47}$

As noted above, the Advisory Committee concluded that this latter construction is correct, meaning that the Rules do not restrict a defendant's ability to admit exculpatory statements made during plea discussions. ${ }^{48}$ Indeed, ostensibly based upon this clarification, Congress amended the Rules so that there is an exception under which a statement is admissible "'in any proceeding wherein another statement made in the course of the same plea or plea discussions has been introduced and the statement ought in fairness be considered contemporaneously with it." According to the Advisory Committee,

[t]his change [was] necessary so that, when evidence of statements made in the course of or as a consequence of a certain plea or plea discussions are introduced under circumstances not prohibited by this rule (e.g., not "against" the person who made the plea), other statements relating to the same plea or plea discussions may also be admitted when relevant to the matter at issue. ${ }^{50}$

As an example, the Advisory Committee noted that "if a defendant... were able to admit certain statements made in aborted plea discussions in his favor, then other relevant statements made in the same plea discussions should be admissible against the defendant in the interest of determining the truth of the matter at issue."51

Former Federal Rule of Criminal Procedure 11(e)(6) is now Federal Rule of Criminal Procedure 11(f), ${ }^{52}$ and it merely states that "[t]he admissibility or inadmissibility of a plea, a plea discussion, and any related statement is governed by Federal Rule of Evidence 410."53 Meanwhile, Rule 410 now sets forth:

Except as otherwise provided in this rule, evidence of the following is not, in any civil or criminal proceeding, admissible against the

\footnotetext{
47. FED. R. CRIM. P. 11 advisory committee's note.

48. See supra note 42 and accompanying text.

49. FED. R. CRIM. P. 11 advisory committee's note (quoting FED. R. CRIM. P. 11(e)(6) (1979 amendment)).

50. Id.

51. Id.

52. Compare FED. R. CRIM. P. 11(e)(6) (2001) (repealed 2002) (former rule regarding admissibility of plea discussion), with FED. R. CRIM. P. 11(f) (current rule regarding admissibility of plea discussions).

53. FED. R. CRIM. P. 11(f).
} 
defendant who made the plea or was a participant in the plea discussions:

(1) a plea of guilty which was later withdrawn;

(2) a plea of nolo contendere;

(3) any statement made in the course of any proceedings under Rule 11 of the Federal Rules of Criminal Procedure or comparable state procedure regarding either of the foregoing pleas; or

(4) any statement made in the course of plea discussions with an attorney for the prosecuting authority which do not result in a plea of guilty or which result in a plea of guilty later withdrawn.

However, such a statement is admissible (i) in any proceeding wherein another statement made in the course of the same plea or plea discussions has been introduced and the statement ought in fairness be considered contemporaneously with it, or (ii) in a criminal proceeding for perjury or false statement if the statement was made by the defendant under oath, on the record and in the presence of counsel. ${ }^{54}$

III. COURTS' CATEGORICAL EXCLUSION OF EVIDENCE THAT DEFENDANTS REJECTED FAVORABLE PLEA BARGAINS

\section{A. United States v. Verdoorn and the Initial Proscription on Evidence of Rejected Plea Deals}

The Eighth Circuit case United States v. Verdoorn was the first case after the passage of Rules 410 and 11(e)(6) to address the admissibility of evidence that a defendant rejected a favorable plea bargain. ${ }^{55}$ In Verdoorn, several defendants were charged in connection with a conspiracy to steal an interstate shipment of beef. ${ }^{56}$ After conviction, defendants David and Maynard Verdoorn appealed, claiming that the district court erred by precluding them from presenting evidence that the government offered each of the alleged co-conspirators plea deals in exchange for their testimony. ${ }^{57}$ According to the defendants, this evidence would have "challenge[d] the credibility of the government's

\footnotetext{
54. FED. R. EVID. 410.

55. 528 F.2d 103 (8th Cir. 1976).

56. Id. at 104 .

57. Id. at 107 .
} 
entire case, i.e., disclose[d] the lengths to which the government went in attempting to obtain vital testimony to prosecute its case." ${ }^{\text {. }}$

The Eighth Circuit disagreed, finding that "[u]nder the rationale of [Federal Rule of Evidence] 408, which relates to the general inadmissibility of compromises and offers to compromise, government proposals concerning pleas should be excludable."59 At the time, Federal Rule of Evidence 408 provided:

"Evidence of (1) furnishing or offering or promising to furnish, or (2) accepting or offering or promising to accept, a valuable consideration in compromising or attempting to compromise a claim which was disputed as to either validity or amount, is not admissible to prove liability for or invalidity of the claim or its amount. Evidence of conduct or statements made in compromise negotiations is likewise not admissible. This rule does not require the exclusion of any evidence otherwise discoverable merely because it is presented in the course of compromise negotiations. This rule also does not require exclusion when the evidence is offered for another purpose, such as proving bias or prejudice of a witness, negativing a contention of undue delay, or proving an effort to obstruct a criminal investigation or prosecution."

When the Eighth Circuit decided Verdoorn, many courts held that Rule 408 only governed settlement negotiations between parties in civil cases based upon the policy that pretrial compromises should be encouraged in such cases. ${ }^{61}$ The Eighth Circuit, however, found that the rationale of Rule 408 extended to criminal cases because of the policy that plea bargains should be encouraged in such cases. ${ }^{62}$ According to the court, "[i]f such a policy is to be fostered, it is essential that plea negotiations remain confidential to the parties if they are unsuccessful." 63 In closing, the court concluded that "[m]eaningful dialogue between the parties would, as a practical matter, be impossible if either party had to assume the risk that plea offers would be admissible in evidence.”,

Other courts at both the state and federal levels soon fell into lockstep with the Eighth Circuit, consistently deeming evidence of

\footnotetext{
58. Id.

59. Id.

60. Ramada Dev. Co. v. Rauch, 644 F.2d 1097, 1106 (5th Cir. 1981) (quoting FED. R. EviD. 408 (1981) (amended 2006)).

61. See Miller, supra note 36, at 733 n.47; see also, e.g., United States v. Baker, 926 F.2d 179, 180 (2d Cir. 1991) ("We believe it fairly evident that the Rule applies only to civil litigation.").

62. Verdoorn, 528 F.2d at 107.

63. Id.

64. Id.
} 
rejected plea bargains inadmissible but not always for the same reasons. For instance, in Moss v. State, the Court of Appeals of Texas relied upon the Rule 408 reasoning of Verdoorn in affirming the trial court's exclusion of evidence that the defendant, who was convicted of murder and sentenced to ninety-nine years incarceration, rejected a plea bargain under which the prosecutor would have recommended only twenty-five years imprisonment. ${ }^{65}$ In cases like the Supreme Court of Indiana's opinion in Wright $v$. State $e^{66}$ and the opinion of the United States District Court for the Northern District of Illinois in United States v. Craig, ${ }^{67}$ courts have found that Rule 410's proscription on the admission of evidence of statements made during plea discussions "against the defendant" should also apply to statements presented by the defendant. And, in cases like Woodsum, ${ }^{68}$ discussed in the Introduction to this Article, and the Court of Appeals of Ohio's opinion in State v. Davis, ${ }^{69}$ courts have excluded evidence of rejected favorable plea bargains by concluding that such evidence fails the balancing test laid out in Federal Rule of Evidence 403 (and state counterparts), which provides that "[a]lthough relevant, evidence may be excluded if its probative value is substantially outweighed by the danger of unfair prejudice, confusion of the issues, or misleading the jury, or by considerations of undue delay, waste of time, or needless presentation of cumulative evidence." ${ }^{, 70}$

In its 1991 opinion in State v. Pearson, the Court of Appeals of Utah accurately summarized the state of this area of the law by precluding a defendant from presenting evidence that he rejected a favorable plea bargain, in the process noting that it had "found no appellate decisions which have reached a contrary result, given the narrow issue before

65. 860 S.W.2d 194, 196-97 (Tex. App. 1993) (interpreting a state rule of evidence modeled after Federal Rule of Evidence 408).

66. 363 N.E.2d 1221, 1228 (Ind. 1977) ("We hold that any communication or evidence relating to plea bargaining negotiations offered in evidence by the defendant is inadmissible unless the defendant subsequently enters a plea of guilty which is not withdrawn.”).

67. No. 87 CR 436-1 \& 2, 1987 WL 20415, at *6 (N.D. Ill. Oct. 26, 1987) (“As the government states, such references to plea negotiations are inadmissible against a defendant under Rule 410 of the Federal Rules of Evidence.... This Court believes that they should also not be admissible by a defendant.”).

68. See supra notes $1-16$ and accompanying text.

69. 434 N.E.2d 285, 288 (Ohio Ct. App. 1980) ("Stated simply, it is that the probative value, if any, of evidence relating to settlement negotiations is far outweighed by its possible prejudicial and misleading effect upon the jury.” (citing a state counterpart of FED. R. EVID. 403, OHIO R. EVID. 403)).

70. FED. R. EVID. 403. 
us." ${ }^{\text {71 }}$ A year earlier, however, the Second Circuit had decided a case that could have stemmed the tide.

\section{B. United States v. Biaggi and the Admissibility of Evidence of Rejected Immunity Deals}

In United States v. Biaggi, six defendants, including John Mariotta, were charged with a variety of state and federal violations in connection with misconduct allegedly committed at Wedtech Corp., a manufacturing company that received contracts from the Defense Department. ${ }^{72}$ The defendants were convicted and thereafter appealed, with Mariotta claiming, inter alia, that the district court erred by precluding him from presenting evidence that he rejected a deal under which he would have been given immunity in exchange for his testimony against other Wedtech officers and public officials. ${ }^{73}$ According to Mariotta, he rejected this offer of immunity by claiming that he had no knowledge of any wrongdoing by these officials, making his rejection of the offer evidence of his "“consciousness of innocence."”74 The Second Circuit agreed, concluding that "[t]he available inference is that he really lacked such knowledge, as he claimed throughout the trial."75

The Second Circuit did acknowledge the government's argument "that evidence of immunity negotiations should be excluded because of the same considerations that bar evidence of plea negotiations."76 As a preliminary note, however, the court advised "that plea negotiations are inadmissible 'against the defendant,' and it does not necessarily follow that the Government is entitled to a similar shield."77

The Second Circuit then found, even without this conclusion, that evidence of an immunity negotiation has more probative value than evidence of a plea negotiation. ${ }^{78}$ On the one hand, "[w] hen a defendant rejects an offer of immunity on the ground that he is unaware of any wrongdoing about which he could testify, his action is probative of a state of mind devoid of guilty knowledge." ${ }^{, 79}$ The court did acknowledge

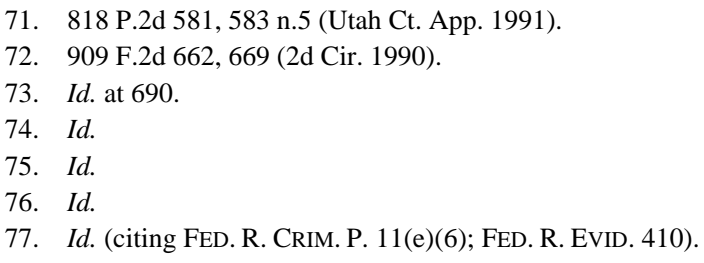


that "there may be reasons for rejecting the offer that are consistent with guilty knowledge, such as fear of reprisal from those who would be inculpated." ${ }^{\circ 0}$ Nonetheless, the Second Circuit found that "a jury is entitled to believe that most people would jump at the chance to obtain an assurance of immunity from prosecution and to infer from rejection of the offer that the accused lacks knowledge of wrongdoing." ${ }^{81}$ According to the court, "[t]hat the jury might not draw the inference urged by the defendant does not strip the evidence of probative force." 82

The court also acknowledged on the other hand that "[r]ejection of an offer to plead guilty to reduced charges could also evidence an innocent state of mind." 83 The court concluded, though, that "the inference is not nearly so strong as rejection of an opportunity to preclude all exposure to a conviction and its consequences." ${ }^{84}$ Instead, "[a] plea rejection might simply mean that the defendant prefers to take his chances on an acquittal by the jury, rather than accept the certainty of punishment after a guilty plea.”, ${ }^{\text {, }}$

But the court then noted that it was not its task to "decide whether a defendant is entitled to have admitted a rejected plea bargain." ${ }^{\text {, }}$ Instead, it merely had to resolve the issue of whether a defendant can present evidence of a rejected immunity offer, and it determined that "[t]he probative force of a rejected immunity offer is clearly strong enough to render it relevant [under Federal Rule of Evidence] 401."87 As support for this determination, the court cited esteemed evidence scholar Dean Wigmore, who argued:

"Let the accused's whole conduct come in; and whether it tells for consciousness of guilt or for consciousness of innocence, let us take it for what it is worth, remembering that in either case it is open to varying explanations and is not to be emphasized. Let us not deprive an innocent person, falsely accused, of the inference which common sense draws from a consciousness of innocence and its natural manifestations."
80. Id.
81. Id.
82. Id. at 690-91.
83. Id. at 691.
84. Id.
85. Id.
86. Id.
87. Id.
88. Id. (quoting 2 WIGMORE ON EVIDENCE § 293, at 232 (J. Chadbourn rev. ed. 1979)). 
The court found that it was a "closer question" whether the district court abused its discretion by (implicitly) finding that evidence of the rejected immunity offer failed the balancing test prescribed by Federal Rule of Evidence $403 .^{89}$ In the end, though, the court found such abuse based upon the high probative value of the evidence and concluded that "the exclusion of Mariotta's state of mind evidence denied him a fair trial." 90

Biaggi is ostensibly "the leading case on the issue" of whether defendants can present evidence that they rejected offers of immunity, and the Second Circuit's opinion "represents the way most courts handle the admissibility of evidence of ... immunity offers and statements made by the government in discussing such offers." ${ }^{91}$ For instance, in United States v. Maloof, the government began building an antitrust case against Bay Industries, Inc., a company where Mark Maloof worked as the southern regional sales manager. ${ }^{92}$ In June 1995, governmental officials twice offered Maloof immunity if he surreptitiously recorded conversations with his employer and other individuals. ${ }^{93}$ Maloof declined these offers of immunity, and in May 1997, he was indicted on counts of conspiracy to restrain trade and conspiracy to commit wire fraud. ${ }^{94}$ At trial, the district court permitted Maloof to testify "to the substance of the conversations relating to the offers of immunity, his rejection of the offers and his explanation of lack of knowledge of wrongdoing." 95 The court, however, precluded him from testifying about "what he considered to be threats and attempted intimidation of him by the government agents." the Fifth Circuit affirmed, concluding

that the trial court correctly applied [Federal Rules of Evidence] 401, 410, and 403 as interpreted in Biaggi by allowing Maloof to testify to the sum and substance of the offers and rejections of immunity; and did not abuse its discretion under [Rule] 403 to bar embellishing details on

\footnotetext{
89. Id.

90. Id.

91. Mark T. Pavkov, Note, Closing the Gap: Interpreting Federal Rule of Evidence 408 to Exclude Evidence of Offers and Statements Made by Prosecutors During Plea Negotiations, 57 CASE W. RES. L. REV. 453, 465-66 (2007).

92. 205 F.3d 819, 823 (5th Cir. 2000).

93. Id. at $824-25$.

94. Id. at 824 .

95. Id. at 825 .

96. Id.
} 
the grounds that their probative value was outweighed by the danger of unfair prejudice, confusion, or delay. ${ }^{97}$

\section{Immune to Biaggi: Courts' Continued Reluctance to Admit Evidence that Defendants Rejected Favorable Plea Bargains}

Biaggi stands for the proposition that a defendant can present evidence that he rejected an immunity offer, but the Second Circuit left open the question of whether a defendant can present evidence that he rejected a plea offer. According to the Second Circuit, evidence that a defendant rejected a plea bargain is less probative of a defendant's innocent state of mind than a defendant's rejection of an offer of immunity. ${ }^{98}$ But is it probative enough to pass the Rule 403 balancing test? In the wake of Biaggi, no court has answered this question in the affirmative.

The Second Circuit itself had an opportunity to revisit the issue in its 2001 opinion in United States v. Samaria, which current Supreme Court Justice Sonia Sotomayor authored. ${ }^{99}$ In Samaria, Frank Elaiho and others were indicted on several felony charges based on their alleged participation in a complex credit card scheme. ${ }^{100}$ Elaiho rejected a plea deal under which he would have pleaded guilty to a lesser misdemeanor charge, and the district judge later prevented him from presenting evidence of his rejection. ${ }^{101}$ Elaiho was eventually convicted of conspiring to receive or possess stolen goods, conspiring to commit credit card fraud, committing credit card fraud, and aiding and abetting credit card fraud, felony convictions that would have resulted in his deportation. ${ }^{102}$ Elaiho thereafter appealed, claiming, inter alia, that his convictions were based upon legally insufficient evidence and that the district court erred in precluding him from presenting evidence that he rejected the plea deal. ${ }^{103}$ The Second Circuit reversed his convictions, finding that they were not supported by legally sufficient evidence. ${ }^{104}$

\footnotetext{
97. Id.

98. See supra notes $83-85$ and accompanying text.

99. 239 F.3d 228 (2d Cir. 2001), abrogated by United States v. Huezo, 546 F.3d 174 (2d Cir. 2008).

100. Id. at 231-32.

101. Id. at 242 .

102. Id. at 231 .

103. Id. at $240-42$.

104. Id. at 242 .
} 
With regard to Elaiho's plea-related claim, the Second Circuit noted that "[i]n United States $v$. Biaggi, ... we held that there was no per se bar to the admissibility of evidence that a defendant had rejected the government's offer of immunity, and assumed that no such bar would prevent the admission of evidence that a defendant had rejected a plea bargain." 105 Of course, the court also noted that, in Biaggi, "we remarked that an offer of immunity would generally carry more evidentiary weight than a rejected plea bargain.”106 Elaiho’s claim was "that his rejection of the opportunity to plea to a lesser misdemeanor charge was particularly relevant to and probative of his consciousness of innocence because accepting such a plea would have prevented his deportation as a legal permanent resident."107 But because the court had already decided it was reversing Elaiho's convictions on other grounds, it found that it did not need to resolve this issue. ${ }^{108}$

Courts that have resolved this issue, however, have been universally consistent with pre-Biaggi precedent. Instead of finding that Biaggi opened the door for defendants admitting evidence that they rejected plea bargains, courts have used Biaggi's explanation of the differences in probative value between evidence of rejections of immunity offers and plea offers to keep the door shut. For instance, in United States v. Japalucci, the United States District Court for the Western District of Pennsylvania cited Biaggi for the alleged proposition that a defendant rejects a plea deal because he "prefers to take his chances on an acquittal by the jury, rather than accept the certainty of a punishment after a guilty plea."109

Other courts have rejected appellants' arguments that Biaggi extends to evidence of rejected plea bargains and added another reason for continuing to deem such evidence inadmissible: the rule against hearsay. In United States v. Greene, the Eighth Circuit rejected the appellant's citation to Biaggi and went on to find that evidence that he rejected a plea bargain was merely "a prior statement consistent with his plea of not guilty." 110 And according to the court, "[s]uch statements, when offered by the defendant, are hearsay, except in narrow circumstances not present here." ${ }^{111}$ Meanwhile, in United States v. Kemp, the United States

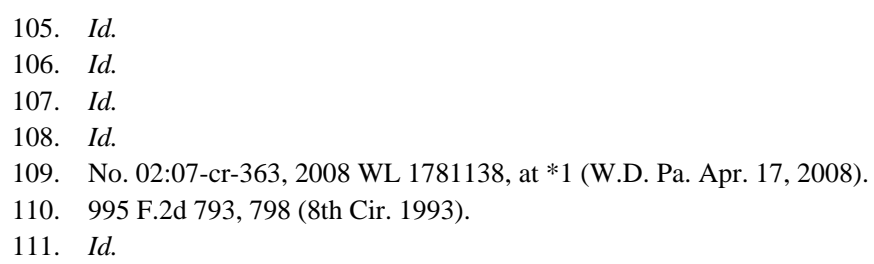


District Court for the Eastern District of Pennsylvania also rejected an appellant's citation to Biaggi in a case in which the appellant rejected the government's offer of leniency in exchange for cooperation after speaking with a lawyer recommended by the FBI. ${ }^{112}$ The court further noted that "[d]efendants' own assertions of their innocence after they were confronted are self-serving, hearsay, and not admissible" and that "[t]hird-party statements"-namely, the statements by the recommended attorney- "are hearsay and not admissible under [Federal Rule of Evidence] 803(3)."113

\section{United STATES V. MEZZANATTO AND THE ABILITY OF PROSECUTORS TO ForCE DEFENDANTS TO WAIVE THE PROTECTIONS OF THE PLEA BARGAINING RULES}

\section{A. United States v. Mezzanatto and the Impeachment Waiver}

In United States v. Mezzanatto, the Ninth Circuit was confronted with an issue of first impression: "whether a defendant may waive the prohibition against the introduction of statements made during plea negotiations." 114 In Mezzanatto, agents arrested Gordon Shuster after government surveillance detected that he was operating a methamphetamine laboratory out of his residence. ${ }^{115}$ Shuster then agreed to play ball with the agents and called Gary Mezzanatto to set up a drug buy between Mezzanatto and an undercover officer. ${ }^{116}$ Mezzanatto subsequently arrived at the buy and presented a brown paper bag with about one pound of methamphetamine and a glass pipe to the officer and asked if he wanted to take a "'hit.","117 The officer gave a prearranged arrest signal, leading to agents arresting Mezzanatto and the State charging him with possession of methamphetamine. ${ }^{118}$

Mezzanatto and his attorney thereafter asked to meet with the prosecutor to see if Mezzanatto could also play ball, and the prosecutor informed them that as a condition to proceeding with a plea meeting, Mezzanatto "would have to agree that any statements he made during the meeting could be used to impeach any contradictory testimony he might

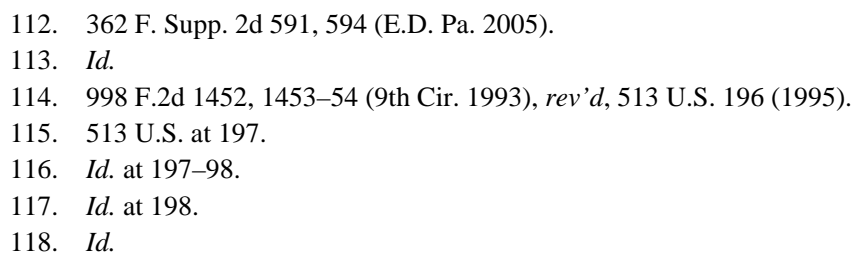


give at trial if the case proceeded that far."119 Mezzanatto agreed to this term and began weaving a tale to the prosecutor, initially admitting that he knew that the bag he tried to sell the officer contained methamphetamine, "but insist[ing] that he had dealt only in 'ounce' quantities of methamphetamine prior to his arrest."120 Mezzanatto also asserted "that he was acting merely as a broker for Shuster and did not know that Shuster was manufacturing methamphetamine at his residence, but he later conceded that he knew about Shuster's laboratory."121 Now clearly grasping at straws, Mezzanatto tried to distance himself from Shuster by claiming "that he had not visited Shuster's residence for at least a week before his arrest." "122 The prosecutor responded not with a plea bargain but with surveillance evidence revealing that Mezzanatto's car was parked at Shuster's residence a mere day before Mezzanatto's arrest. $^{123}$ The prosecutor then cut the meeting short because of Mezzanatto's dishonesty, and the case eventually proceeded to trial. ${ }^{124}$

At trial, Mezzanatto began telling tales again, testifying that he was not involved in methamphetamine trafficking and that he was unaware that Shuster was running a meth lab or that the bag he tried to sell to the agent contained methamphetamine. ${ }^{125}$ Over defense counsel's objection, the prosecutor proceeded to impeach Mezzanatto through his prior inconsistent statements during the plea meeting. ${ }^{126}$

After Mezzanatto was convicted, he appealed, claiming, inter alia, that defendants cannot waive the prohibitions against the introduction of plea negotiation statements contained in Federal Rule of Evidence 410 and Federal Rule of Criminal Procedure 11(e)(6). ${ }^{127}$ The Ninth Circuit agreed, first noting the importance to both the accused and accuser of plea bargains: "They allow criminal cases to be resolved in a quick and cost-effective manner while maintaining the just administration necessary to the criminal justice system.”128

The court then found that the lynchpin of the American plea bargaining mechanism is the guarantee that a defendant can "maximize

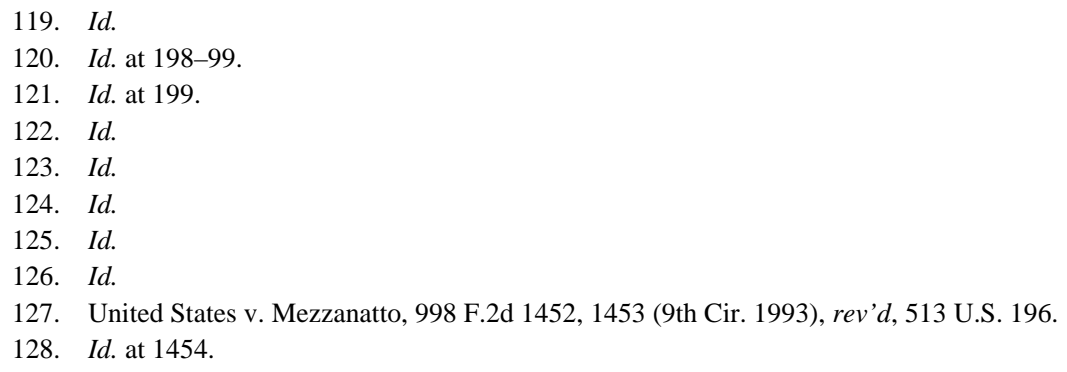


what he has 'to sell' with the ability to withdraw from the bargain proposed by the prosecutor without being harmed by any of his statements made in the course of an aborted plea bargaining session.”129 If courts removed this lynchpin by allowing accuseds to waive this protection, the plea bargaining system might not fall apart, but "candid and effective plea bargaining could be severely injured." 130 Such a result would thus be "contrary to all that Congress intended to achieve."131

The government thereafter appealed to the United States Supreme Court, which reversed, finding that criminal defendants may indeed waive the prohibition against the introduction of plea negotiations statements. ${ }^{132}$ In an opinion authored by Justice Thomas and joined by three other Justices, the Court noted that criminal defendants may voluntarily waive most constitutional protections and statutory provisions. ${ }^{133}$ The Court then went on to find that its cases interpreting both the Federal Rules of Criminal Procedure and Rules of Evidence were consistent with this presumption of waivability, with this presumption finding "specific application in the context of evidentiary rules."134 The Court held that Mezzanatto bore "the responsibility of identifying some affirmative basis for concluding that the plea-statement Rules depart from the presumption of waivability.”135

Justice Thomas then identified but dismissed three such bases raised by Mezzanatto in his appeal. ${ }^{136}$ First, Mezzanatto claimed that Rules 410 and 11(e)(6) established an unwaiveable "'guarantee [to] fair procedure.”,137 The Court actually agreed with Mezzanatto's general premise that some evidentiary provisions could never be waived by criminal defendants without "irreparably 'discredit[ing] the federal courts.",138 To wit, the Court actually cited to, inter alia, the Seventh Circuit's opinion in United States v. Josefik, in which Judge Posner concluded that "'if the parties stipulated to trial by 12 orangutans the defendant's conviction would be invalid notwithstanding his consent, because some minimum of civilized procedure is required by community

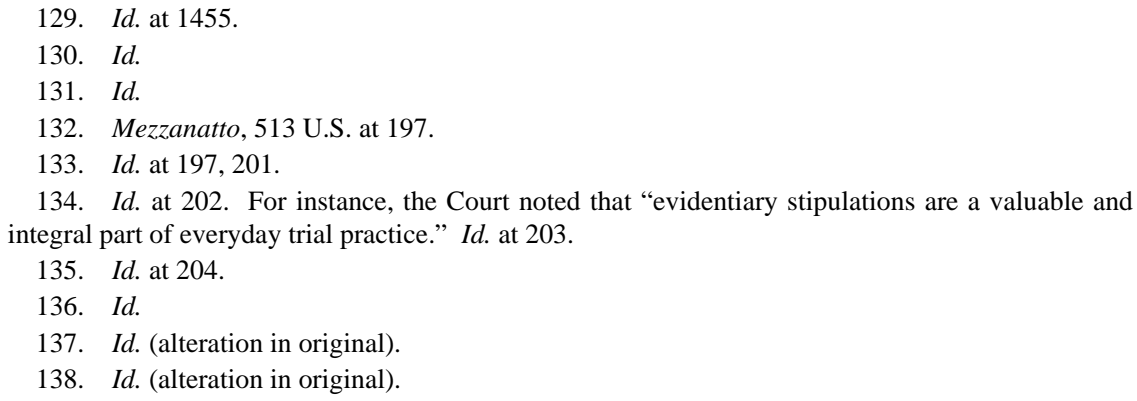


feeling regardless of what the defendant wants or is willing to accept., "139

Justice Thomas, however, did not find the waiver of the prohibition against the introduction of plea negotiation statements analogous to Judge Posner's "twelve monkeys" hypothetical because "[t]he admission of plea statements for impeachment purposes enhances the truth-seeking function of trials and will result in more accurate verdicts."140 According to Justice Thomas, if a defendant such as Mezzanatto made a false statement either during plea bargaining or at trial, "making the jury aware of the inconsistency will tend to increase the reliability of the verdict without risking institutional harm to the federal courts."141

In this same vein, Mezzanatto tried to analogize Rules 410 and 11(e)(6) to Federal Rule of Criminal Procedure 24(c), which at the time stated that " " [a]n alternate juror who does not replace a regular juror shall be discharged after the jury retires to consider its verdict.",142 Mezzanatto noted that Justice Kennedy suggested in his concurrence in United States $v$. Olano ${ }^{143}$ that the protections of Rule 24(c) can never be waived by an agreement allowing an alternate juror to sit in on deliberations, and Mezzanatto argued that the same should apply to Rules 410 and 11(e)(6). ${ }^{144}$ The Court again disagreed because the plearelated Rules "provide that statements made in the course of plea discussions are inadmissible 'against' the defendant, and thus leave open the possibility that a defendant may offer such statements into evidence for his own tactical advantage." Rules do more than leave open this possibility; instead, "the Rules contemplate this result in permitting admission of statements made 'in any proceeding wherein another statement made in the course of the same ... plea discussions has been introduced and the statement ought in fairness be considered contemporaneously with it.",146 In summation, the Court concluded that "the plea-statement Rules expressly contemplate a degree of party control that is consonant with the background presumption of waivability."147

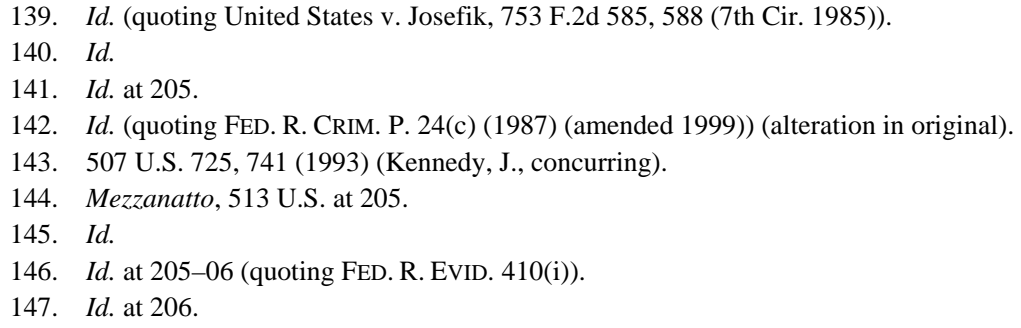


Second, Mezzanatto argued that a policy of allowing waiver of the plea-statement rules could not be reconciled with the main goal of these rules: encouraging voluntary settlements. ${ }^{148}$ While the Ninth Circuit had agreed with this argument, the Supreme Court disagreed, finding that "[t]he court below focused entirely on the defendant's incentives and completely ignored the other essential party to the transaction: the prosecutor." 149 Justice Thomas acknowledged on the one hand that "the availability of waiver may discourage some defendants from negotiating," but he found on the other that "it is also true that prosecutors may be unwilling to proceed without it."150

Accordingly, the Court held that, "as a logical matter, it simply makes no sense to conclude that mutual settlement will be encouraged by precluding negotiation over an issue that may be particularly important to one of the parties to the transaction."151 Rather, the Court decided that "[a] sounder way to encourage settlement is to permit the interested parties to enter into knowing and voluntary negotiations without any arbitrary limits on their bargaining chips.”152 Borrowing a metaphor used by the Ninth Circuit in its opinion below, the Court couched the matter in terms of economics:

[I]f the prosecutor is interested in "buying" the reliability assurance that accompanies a waiver agreement, then precluding waiver can only stifle the market for plea bargains. A defendant can "maximize" what he has to "sell" only if he is permitted to offer what the prosecutor is most interested in buying. And while it is certainly true that prosecutors often need help from the small fish in a conspiracy in order to catch the big ones, that is no reason to preclude waiver altogether. If prosecutors decide that certain crucial information will be gained only by preserving the inadmissibility of plea statements, they will agree to leave intact the exclusionary provisions of the plea-statement Rules.

Third, Mezzanatto asserted "that waiver agreements should be forbidden because they invite prosecutorial overreaching and abuse."154 Specifically, he alleged "that there is a 'gross disparity' in the relative bargaining power of the parties to a plea agreement and suggest[ed] that

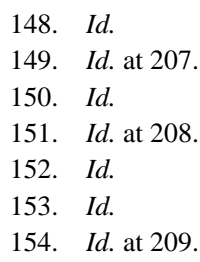


a waiver agreement is 'inherently unfair and coercive.",155 Justice Thomas again turned this argument aside, observing that " $[\mathrm{t}] \mathrm{he}$ dilemma flagged by [Mezzanatto] [was] indistinguishable from any of a number of difficult choices that criminal defendants face every day."156 According to Justice Thomas, "[t]he plea bargaining process necessarily exerts pressure on defendants to plead guilty and to abandon a series of fundamental rights, but we have repeatedly held that the government 'may encourage a guilty plea by offering substantial benefits in return for the plea.",157

In a concurring opinion joined by Justices O'Connor and Breyer, Justice Ginsburg noted that the Court merely held "that a waiver allowing the Government to impeach with statements made during plea negotiations is compatible with Congress' intent to promote plea bargaining." 158 She cautioned, though, that "[i]t may be . . . that a waiver to use such statements in the case in chief would more severely undermine a defendant's incentive to negotiate, and thereby inhibit plea bargaining." 159 But because the waiver at issue was not this type of waiver, she left this issue for another day. ${ }^{160}$

Meanwhile, in an opinion joined by Justice Stevens, Justice Souter dissented, expressing Justice Ginsburg's concern in a different manner. According to Justice Souter, "although the erosion of the Rules has begun with this trickle, the majority's reasoning will provide no principled limit to it." "61 This is because "[t]he Rules draw no distinction between use of a statement for impeachment and use in the Government's case in chief."162 Therefore, "[i]f objection can be waived for impeachment use, it can be waived for use as affirmative evidence, and if the Government can effectively demand waiver in the former instance, there is no reason to believe it will not do so just as successfully in the latter." 163 Justice Souter then warned that "[w]hen it does, there is nothing this Court will legitimately be able to do about it."164

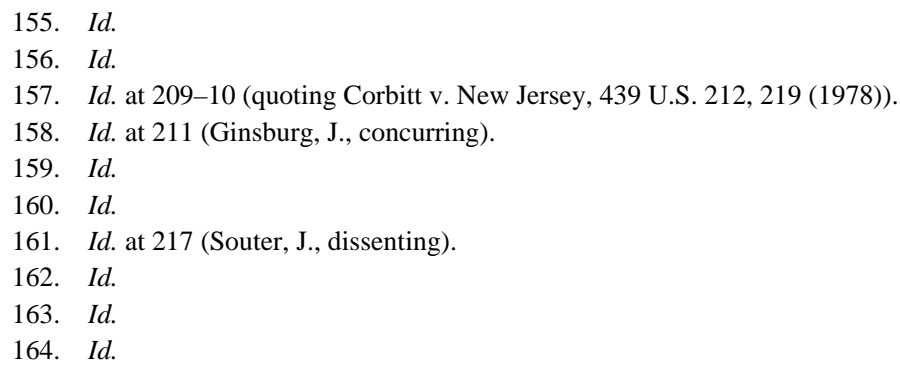




\section{B. Mezzanatto’s Aftermath: Case-in-Chief Waivers and Rebuttal Waivers}

Since Mezzanatto, three circuits have addressed the issue raised by Justice Ginsburg: whether, as a precondition for plea bargaining, a prosecutor can force a criminal defendant to sign a waiver allowing for the use of the defendant's statements during plea negotiations as part of the prosecution's case-in-chief, regardless of whether the defendant testifies at trial. ${ }^{165}$ Each of these circuits, the D.C. Circuit and the Fifth and Eighth Circuits, have endorsed these types of waivers. ${ }^{166}$

In the Fifth Circuit case, United States v. Sylvester, Donald Sylvester voluntarily surrendered after the government obtained an arrest warrant for him in connection with his alleged killing of a witness for the prosecution in a federal case involving a large-scale drug conspiracy. ${ }^{167}$ Assistant United States Attorney Martin Landrieu then presented him with some of the evidence against him, such as an alleged co-conspirator fingering him as the murderer and cocaine, a newspaper noting the killing, and rap lyrics describing a similar murder recovered from Sylvester's car. ${ }^{168}$ Landrieu followed up this presentation with another vital piece of information: the Attorney General could seek the death penalty because Sylvester was accused of murdering a federal witness. ${ }^{169}$ Landrieu then explained that he would ask permission from the Attorney General to seek life imprisonment but only if Sylvester confessed to the crime and waived any objection to the admission of his incriminatory statements, even during the prosecution's case-in-chief, if plea negotiations failed. ${ }^{170}$

Sylvester signed the waiver and confessed, and Landrieu made his promised recommendation. ${ }^{171}$ Sylvester subsequently had second thoughts, decided to proceed with trial and requested new, courtappointed counsel. ${ }^{172}$ Before that trial, Sylvester moved to suppress his confession, but the district court enforced his waiver and allowed for the

165. See United States v. Mergen, No. 06-CR-352 (NGG), 2010 WL 395974, at *4 (E.D.N.Y. Feb. 3, 2010) (citing United States v. Sylvester, 583 F.3d 285 (5th Cir. 2009); United States v. Young, 223 F.3d 905 (8th Cir. 2000); United States v. Burch, 156 F.3d 1315 (D.C. Cir. 1998)).

166. See id. (noting that each of these circuits have held such "provisions to be enforceable").

167. 583 F.3d at 287.

168. Id.

169. Id.

170. Id.

171. Id

172. Id. 
prosecution to use his confession as part of its case-in-chief to procure Sylvester's conviction. ${ }^{173}$

Sylvester thereafter appealed, and the Fifth Circuit noted Justice Ginsburg's concurring opinion in Mezzanatto in which she questioned whether this broader type of waiver was compatible with Congress' intent to promote plea bargaining. ${ }^{174}$ The court then cited Justice Thomas' rejection of the three bases cited by Mezzanatto for finding that courts should not allow defendants to waive the plea-statement Rules so that prosecutors can use their statements during plea negotiations to impeach their contradictory testimony at trial. ${ }^{175}$ And just as Justice Souter feared, the Fifth Circuit approved of the waiver because it could “find no convincing reason for not extending Mezzanatto's rationale to this case." 176

In finding that the rules are waiveable, the Fifth Circuit reiterated the Supreme Court's points that “[a] defendant may himself introduce his own plea statements, and indeed, the Rules themselves contemplate such a result" 177 and that courts better encourage settlement by allowing both sides to enter negotiations without arbitrary limits on their bargaining chips. ${ }^{178}$ The court acknowledged that "an innocent defendant might execute such a waiver (and thus inject false statements into the admissible record)" but ultimately found that "the benefit of evaluating as much relevant evidence as possible outweighs the mere possibility of such danger, and will, on balance, enhance the reliability of a factfinder's conclusions." 179

In United States v. Burch, the D.C. Circuit reached the same conclusion by also extending Justice Thomas' rejection of Mezzanatto's three proposed bases for precluding impeachment waivers to a defendant's arguments for precluding case-in-chief waivers. ${ }^{180}$ And in United States v. Young, the Eighth Circuit deemed a case-in-chief waiver valid under Mezzanatto because it was knowing and voluntary, without even acknowledging the extension that it had made. ${ }^{181}$ While the First, Fourth, and Tenth Circuits have not yet addressed the issue of whether

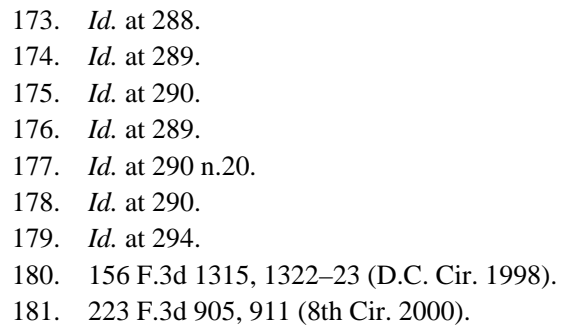


defendants can sign case-in-chief waivers, district courts in each of these circuits have upheld such waivers. ${ }^{182}$

The Second, Third, Sixth, Seventh, Ninth, and Eleventh Circuits also have not yet addressed this issue, but each of these circuits has approved use of rebuttal waivers. ${ }^{183}$ Whereas the impeachment waiver approved by the Court in Mezzanatto permitted a prosecutor to impeach a defendant with his statements during plea negotiations if he provided inconsistent testimony at trial, a rebuttal waiver permits a prosecutor to use a "defendant's plea statements if the defendant presents any evidence at trial that contradicts his plea statements." "184 Exactly "[w]hat constitutes contradictory evidence varies by circuit and the language of a particular plea agreement," 185 but a couple of examples suffice.

In United States $v$. Krilich, Robert Krilich was convicted of conspiracy to violate the Rackateer Influenced and Corrupt Organizations Statute and a fraud statute after he allegedly rigged a holein-one contest so that the mayor's son would win. ${ }^{186}$ Krilich needed the support of the mayor of Oakbrook Terrace, Illinois, to procure a bond for an apartment complex, and Krilich and the mayor came up with an ingenious plan for Krilich to deliver the bribe to the mayor. ${ }^{187}$ Krilich put on a contest in which a golfer who hit a hole-in-one at the ninth hole of the Country Lakes Country Club would win a 1931 Cadillac or a check for $\$ 40,000$, with the prize to be paid by the National Hole-In-One Association, which insured the contest. ${ }^{188}$ Krilich palmed one of the son's golf balls, proceeded to the ninth hole, and, after the son hit his shot, pretended to pull the ball out of the hole. ${ }^{189}$

182. See United States v. DeLaurentiis, 638 F. Supp. 2d 76, 79 (D. Me. 2009); United States v. Mitchell, No. 2:07-CR-149 TS, 2009 WL 1393138, at *4 (D. Utah May 18, 2009); United States v. El-Amin, 268 F. Supp. 2d 639, 642 (E.D. Va. 2003). In Mitchell, the United States District Court for the District of Utah later denied the defendant's motion for continued release pending appeal, noting the only courts of appeal to address the issue have upheld case-in-chief waivers and that "there [was] no reason to believe that the Tenth Circuit would depart from the resolution of this issue by other circuits.” United States v. Mitchell, No. 2:07-CR-149 TS, 2009 WL 2852114, at *3 (D. Utah Sept. 1, 2009).

183. United States v. Hardwick, 544 F.3d 565, 570 (3d Cir. 2008); United States v. Artis, 261 F. App’x 176, 177-79 (11th Cir. 2008); United States v. Fifer, 206 F. App’x 502, 510 (6th Cir. 2006); United States v. Velez, 354 F.3d 190, 196-97 (2d Cir. 2004); United States v. Rebbe, 314 F.3d 402, 407-08 (9th Cir. 2002); United States v. Krilich, 159 F.3d 1020, 1026 (7th Cir. 1998).

184. United States v. Sylvester, 583 F.3d 285, 291 (5th Cir. 2009).

185. Id. at $291 \mathrm{n} .23$.

186. 159 F.3d at 1024 .

187. Id.

188. Id.

189. Id. 
Krilich was later arrested in connection with this fraud and bribery, and to get to the plea bargaining table, he had to sign a waiver which provided:

[S]hould [Krilich] subsequently testify contrary to the substance of the proffer or otherwise present a position inconsistent with the proffer, nothing shall prevent the government from using the substance of the proffer at sentencing for any purpose, at trial for impeachment or in rebuttal testimony, or in a prosecution for perjury.

During the ensuing plea negotiations, Krilich admitted, inter alia, that he "'faked the hole-in-one on the ninth hole.",191

After Krilich and the government failed to reach a plea agreement, the case proceeded to trial, and Krilich neither testified nor called any witnesses who claimed that Krilich was innocent of the crimes charged. ${ }^{192}$ During cross-examination, however, Krilich's attorney got several witnesses for the prosecution to testify "that the ninth hole at Country Lakes Country Club is close to the clubhouse and easily observed," implying that Krilich would not have the courage to plant the ball. ${ }^{193}$ During cross-examination, Krilich's attorney also got two prosecution "witnesses to say that they were at the ninth hole when [the son] hit the shot but didn't think that Krilich was at the ninth hole then.”194 The United States District Court for the Northern District of Illinois found that by eliciting these and similar responses during crossexamination, Krilich (through his attorney) had presented a position inconsistent with his proffer, opening the door for the prosecution to admit his confession. ${ }^{195}$

On appeal, the Seventh Circuit recognized, regarding the witnesses' testimony about the ninth hole being easily observed, "Krilich wanted the jury to infer that no one would attempt to fake a hole-in-one there."196 And according to the court, "that implication [was] inconsistent with the proffer." 197 Similarly, with regard to the testimony by the two witnesses who did not think that Krilich was at the ninth hole, the court found that "[t]heir testimony implied that Krilich did not fake the hole-in-one,

190. Id

191. Id. at 1025.

192. Id.

193. Id. at 1026.

194. Id.

195. Id.

196. Id

197. Id. 
contrary to what he admitted in his proffer."198 The Seventh Circuit thus affirmed Krilich's conviction because he presented positions inconsistent with his proffer. ${ }^{199}$

In United States v. Barrow, the Second Circuit was presented with a slightly different waiver. ${ }^{200}$ In Barrow, the defendant signed a waiver that allowed the prosecution to use his proffer statements "'to rebut any evidence offered or elicited, or factual assertions made, by or on behalf of [him] at any stage of a criminal prosecution.,"201 According to the Second Circuit, "[f]actual assertions made by a defendant's counsel in an opening argument or on cross-examination plainly fall within this broad language," opening the door for admission of a defendant's proffer. ${ }^{202}$ And like the Seventh Circuit in Krilich, the Second Circuit found that waiver occurs even when defense counsel merely asserts facts implicitly rather than directly. ${ }^{203}$

\section{DEFEndANTS Should Be ABle to Present EVIDENCE THAT THEY REJECTED FAVORABLE PLEA BARGAINS}

\section{A. Rule 410 Should Not Cut Both Ways}

As already noted, some courts have precluded defendants from presenting evidence that they rejected favorable plea bargains by holding that Rule 410's proscription on the admission of evidence of statements made during plea discussions "against the defendant" should also apply to statements presented by the defendant. ${ }^{204}$ Also, all federal appellate courts have allowed case-in-chief or rebuttal waivers by extending Justice Thomas's three prong analysis from Mezzanatto. ${ }^{205}$ Justice Thomas's analysis, however, also makes clear that lower courts cannot continue to preclude defendants from presenting evidence that they rejected favorable plea bargains under Rule 410.

Justice Thomas first rejected Mezzanatto's assertion that the plearelated rules establish an unwaiveable "'guarantee [to] fair

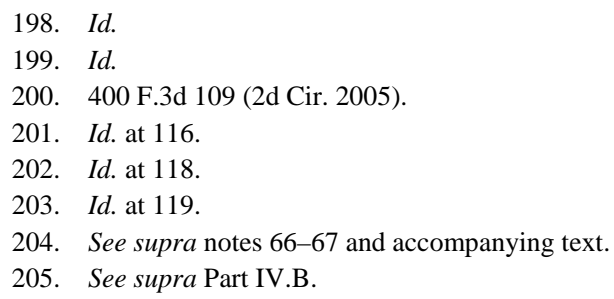


procedure.” ${ }^{206}$ In reaching this conclusion, Justice Thomas relied upon the fact that Rules 410 and 11(e)(6) "provide that statements made in the course of plea discussions are inadmissible 'against' the defendant, and thus leave open the possibility that a defendant may offer such statements into evidence for his own tactical advantage." ${ }^{\text {207 }}$ Justice Thomas then went further, finding that "the Rules contemplate this result in permitting admission of statements made 'in any proceeding wherein another statement made in the course of the same ... plea discussions has been introduced and the statement ought in fairness be considered contemporaneously with it." ${ }^{208}$ He then concluded that "the pleastatement Rules expressly contemplate a degree of party control that is consonant with the background presumption of waivability."209

It is unsurprising that Justice Thomas reached these conclusions in Mezzanatto. As noted, Congress amended Rules 410 and 11(e)(6) in 1979 to make clear the rules do not apply to evidence offered by defendants and to create the fairness exception mentioned by Justice Thomas in Mezzanatto. ${ }^{210}$

Congress amended the Rules based upon the recognition that they allow for the admission of evidence of plea discussions as long as they are not admitted "against the defendant."211 And the Supreme Court found that impeachment waivers are valid in large part based upon the recognition that the Rules contemplate the defendant admitting statements made during plea discussions for his tactical advantage. ${ }^{212}$ So where is the party control expressly contemplated by the Rules and the Supreme Court? According to courts finding that the plea-related Rules cut both ways, defendants lack this control—a result plainly at odds with Mezzanatto, the texts of the Rules, and their legislative histories.

Second, Justice Thomas rejected Mezzanatto's claim that allowing waiver of the plea-statement Rules could not be reconciled with the goal of encouraging voluntary settlements. ${ }^{213}$ The Ninth Circuit had accepted this argument, but Justice Thomas disagreed, finding that "[t]he court below focused entirely on the defendant's incentives and completely

\footnotetext{
206. United States v. Mezzanatto, 513 U.S. 196, 204 (1995) (alteration in original).

207. Id. at 205.

208. Id. at 205-06 (quoting FED. R. EVID. 410(i)).

209. Id. at 206.

210. See supra notes $41-51$ and accompanying text.

211. See supra notes $41-51$ and accompanying text.

212. See supra note 145 and accompanying text.

213. See supra notes $148-53$ and accompanying text.
} 
ignored the other essential party to the transaction: the prosecutor."214 The Court concluded that, "as a logical matter, it simply makes no sense to conclude that mutual settlement will be encouraged by precluding negotiation over an issue that may be particularly important to one of the parties to the transaction." ${ }^{215}$ Instead, the Court decided that "[a] sounder way to encourage settlement is to permit the interested parties to enter into knowing and voluntary negotiations without any arbitrary limits on their bargaining chips.”216

Courts concluding that Rule 410 cuts both ways make the opposite mistake by focusing entirely on the prosecutor's incentives and completely ignoring the other essential party to the transaction: the defendant. Of course, the prosecution would prefer that evidence that a defendant rejected a favorable plea bargain be inadmissible. ${ }^{217}$ But as the aforementioned cases illustrate, ${ }^{218}$ a defendant would just as clearly prefer having the option of presenting evidence that he rejected such a deal to prove his innocent state of mind, the weakness of the prosecution's case, or both. Under Justice Thomas's analysis in Mezzanatto, the sounder way to encourage settlement is not to create an arbitrary limit on the plea-related Rules so that they render evidence of plea discussions inadmissible against both the defendant and the prosecution. Instead, it is more sensible to recognize that the Rules permit defendants to present evidence that they rejected plea agreements and to allow them to use this ability as a bargaining chip during the plea bargaining process. This was the very argument presented by the defendant in Woodsum, discussed in the Introduction to this Article, ${ }^{219}$ and courts' repeated rejection of this argument cannot be reconciled with Mezzanatto.

Moreover, courts would need to do more than reconcile this rejection with Mezzanatto. In Mezzanatto, four Justices approved of impeachment

\footnotetext{
214. Mezzanatto, 513 U.S. at 206.

215. Id. at 208 .

216. Id.

217. But see Brooks v. State, 763 So. 2d 859 (Miss. 2000). In Brooks, the prosecution presented evidence that the defendant rejected a plea bargain. Id. at 862-63. After he was convicted, the defendant appealed, and the Supreme Court of Mississippi noted that neither side cited to "any cases in which the prosecution sought to introduce evidence that a defendant rejected a plea bargain." Id. at 863-64. Nonetheless, relying upon cases in which courts precluded defendants from presenting evidence that they rejected plea deals, the court found that prosecutors also cannot present such evidence and reversed the defendant's conviction. Id. at 864.

218. See supra Parts III.A, C.

219. See supra note 9 and accompanying text.
} 
waivers while two Justices dissented. ${ }^{220}$ The controlling opinion in that case was thus the concurring opinion written by Justice Ginsburg and joined by two other Justices. And as noted, Justice Ginsburg clarified that the Court merely held "that a waiver allowing the Government to impeach with statements made during plea negotiations is compatible with Congress' intent to promote plea bargaining."221 She then cautioned that "[i]t may be ... that a waiver to use such statements in the case in chief would more severely undermine a defendant's incentive to negotiate, and thereby inhibit plea bargaining."222

In other words, the Court did not address the issue of whether rebuttal waivers are compatible with the congressional intent to promote plea bargaining, and the Court called into serious question the issue of whether case-in-chief waivers are compatible with that intent. And yet, as noted, every federal appellate court to address each of these types of waivers has upheld them against constitutional scrutiny. ${ }^{223}$ Given that courts categorically have thrown the concurrence's caution to the wind in extending Mezzanatto, it is difficult to see how they can continue to prevent defendants from presenting evidence that they rejected favorable plea deals on the theory that it might inhibit plea bargaining.

Third, Justice Thomas rejected Mezzanatto's argument “that waiver agreements should be forbidden because they invite prosecutorial overreaching and abuse.”224 Justice Thomas turned this argument aside, finding that "[t]he plea bargaining process necessarily exerts pressure on defendants to plead guilty and to abandon a series of fundamental rights, but we have repeatedly held that the government 'may encourage a guilty plea by offering substantial benefits in return for the plea.",225 If the pressure exerted on defendants in the plea bargaining process is not enough to preclude prosecutors from being able to force defendants to sign waivers of their rights under the plea-related Rules, then, at worst, such pressure does not present a reason for excluding evidence that defendants rejected favorable plea bargains. Moreover, it is at least arguable that this pressure provides some support for the argument that defendants should be able to present such evidence given the power disparity between prosecutors and defendants.

220. See supra notes 133 and 161 and accompanying text.

221. Mezzanatto, 513 U.S. at 211 (Ginsburg, J., dissenting).

222. Id.

223. See supra Part IV.B.

224. Mezzanatto, 513 U.S. at 209.

225. Id. at 209-10 (quoting Corbitt v. New Jersey, 439 U.S. 212, 219 (1978)). 
In summation, each of the three prongs of Justice Thomas' Mezzanatto analysis supports the admission of evidence that defendants rejected favorable plea bargains at least to the same extent as evidence admitted pursuant to impeachment waivers. And each of these prongs supports the admission of such evidence to a greater extent than evidence admitted pursuant to rebuttal and case-in-chief waivers. Thus, unless some rule besides Rule 410 compels the exclusion of such evidence, courts cannot consistently preclude defendants from presenting evidence that they rejected favorable plea bargains while admitting evidence under such impeachment, rebuttal, and case-in-chief waivers.

\section{B. The Rule Against Hearsay Should Not Prevent the Introduction of Evidence that a Defendant Rejected a Favorable Plea Bargain}

Federal Rule of Evidence 801(c) provides that “'[h]earsay” is a statement, other than one made by the declarant while testifying at the trial or hearing, offered in evidence to prove the truth of the matter asserted."226 In addition, Federal Rule of Evidence 802 indicates that "[h]earsay is not admissible except as provided by these rules or by other rules prescribed by the Supreme Court pursuant to statutory authority or by Act of Congress."227 As noted, according to some courts, plea offers by prosecutors and the rejections of those offers by defendants constitute inadmissible hearsay. ${ }^{228}$

Both of these types of statements do meet the Rule 801(c) definition of hearsay. With regard to a plea offer, the offer is a statement made by the declarant - the prosecutor-while not testifying at a trial or hearing, offered in evidence by the defendant to prove the truth of the matter asserted: that the prosecution made a favorable plea offer, which implies that the State thought that it had a weak case. With regard to the defendant's rejection, the rejection is a statement made by the declarant - the defendant-while not testifying at a trial or hearing, offered in evidence by the defendant to prove the truth of the matter asserted: that he rejected a favorable plea offer, which implies that he had an innocent state of mind.

Despite Rule 801(c), however, Federal Rule of Evidence 801(d)(2)(A) provides that "[a] statement is not hearsay if ... [t]he statement is offered against a party and is ... the party's own statement,

\footnotetext{
226. FED. R. EVID. 801(c).

227. FED. R. EVID. 802.

228. See supra notes 111-13 and accompanying text.
} 
in either an individual or a representative capacity."229 Furthermore, Federal Rule of Evidence 801(d)(2)(B) provides that "[a] statement is not hearsay if... [t]he statement is offered against a party and is... a statement of which the party has manifested an adoption or belief in its truth., 230

Under these Rules, it is well established that a civil plaintiff may admit a statement made or adopted by a civil defendant, ${ }^{231}$ a civil defendant may admit a statement made or adopted by a civil plaintiff, ${ }^{232}$ and a prosecutor may admit a statement made or adopted by a criminal defendant. $^{233}$ The statement does not have to resemble a traditional admission; if a party-opponent made or adopted a statement and the other party can establish the "requisite foundation," that party may admit it. ${ }^{234}$ But can a criminal defendant admit a statement made by a prosecutor?

The issue of whether criminal defendants can admit such "statements as admissions of party opponents has been controversial, provoking a split among the circuits." 235 While courts used to rule against criminal defendants on this issue, “'relatively recently several federal courts have endorsed generally the use of inconsistent prosecutorial statements in concluding they are not per se inadmissible.",236 According to these courts, prosecutors' statements are either admissions of prosecutors in their capacity as representatives of the government under Rule 801(d)(2)(A) or admissions adopted by the government under Rule 801(d)(2)(B). ${ }^{237}$

Some of these courts, however, hold that criminal defendants can only admit prosecutors' statements if they are assertions of fact equivalent to a testimonial statement, inconsistent with similar assertions in a subsequent trial, and not subject to an innocent explanation for the

\footnotetext{
229. FED. R. EVID. 801(d)(2)(A).

230. FED. R. EVID. 801(d)(2)(B).

231. See, e.g., Green v. City of New York, 465 F.3d 65, 77 (2d Cir. 2006).

232. See, e.g., Rodriguez v. Modern Handling Equip. of NJ, Inc., 604 F. Supp. 2d 612, 622 (S.D.N.Y. 2009).

233. See, e.g., United States v. DiSantis, 565 F.3d 354, 360 (7th Cir. 2009).

234. See, e.g., Guest v. Allstate Ins. Co., 205 P.3d 844, 861 (N.M. Ct. App. 2009) (noting that a party may introduce an adverse party's statement as an admission as long as it is in some way relevant), aff'd in part, rev'd in part, 244 P.3d 342 (N.M. 2010).

235. United States v. Lopez-Ortiz, 648 F. Supp. 2d 241, 246 (D.P.R. 2009).

236. Id. (quoting State v. Pearce, No. 30502, 2007 WL 1544152, at *11 (Idaho Ct. App. May 30, 2007).

237. Id. at 246-47.
} 
inconsistency. ${ }^{238}$ Under this test, a prosecutor's plea offer would not be an assertion of fact. And while prosecuting a defendant for a more severe crime after offering the defendant an opportunity to plead guilty to a less serious crime could be seen as inconsistent with assertions at trial, the prosecutor could easily explain the inconsistency based upon the way that the plea bargaining process works. Therefore, in these courts, the admission Rules would not allow defendants to present evidence of prosecutors' plea offers. Other courts, however, "have adopted a more permissive approach to the admission of prosecutorial statements by conducting a simple F.R.E. 801(d)(2) analysis without also applying [these] ... factors." ${ }^{239}$ In these courts, defendants should be able to admit evidence of prosecutors' plea offers as admissions.

Conversely, a defendant's rejection of a plea offer would not be admissible as an admission because it would be the defendant seeking to admit his own statement. The aforementioned opinion in United States $v$. Kemp, however, indirectly indicates how both a prosecution's plea offer and a defendant's rejection of it are admissible notwithstanding the rule against hearsay. ${ }^{240}$ As noted, in Kemp, the United States District Court for the Eastern District of Pennsylvania, inter alia, precluded a defendant from presenting evidence concerning statements that a lawyer recommended by the FBI made to him regarding an offer of leniency in exchange for cooperation. ${ }^{241}$ In deeming this evidence inadmissible, the court found that "[t]hird-party statements... are hearsay and not admissible under [Federal Rule of Evidence] 803(3).,"242

This conclusion is actually inaccurate, and Federal Rule of Evidence 803(3) explains how both a prosecutor's plea offer and a defendant's rejection of it are admissible. Federal Rule of Evidence 803(3) provides an exception to the rule against hearsay for

[a] statement of the declarant's then existing state of mind, emotion, sensation, or physical condition (such as intent, plan, motive, design, mental feeling, pain, and bodily health), but not including a statement of memory or belief to prove the fact remembered or believed unless it relates to the execution, revocation, identification, or terms of declarant's will. $^{243}$

\footnotetext{
238. Pearce, 2007 WL 1544152, at *11.

239. Id. at *11 n.8.

240. See supra note 112 and accompanying text.

241. See supra notes $112-13$ and accompanying text.

242. United States v. Kemp, 362 F. Supp. 2d 591, 594 (E.D. Pa. 2005).

243. FED. R. EVID. 803(3).
} 
While the Eastern District of Pennsylvania found that Rule 803(3) does not cover third-party statements in Kemp, ${ }^{244}$ it reached the opposite conclusion in Kraft General Foods, Inc. v. BC-USA, Inc. ${ }^{245}$ In BC-USA, Kraft General Foods, Inc., which manufactures "Philadelphia" cream cheese, brought a trademark infringement action against a company which manufactured "Pennsylvania" cream cheese and had a pending trademark registration for "Pennsylvania" in Argentina. ${ }^{246}$ At trial,

[d] uring the direct examination of Jorge Bertran-Guzman, Kraft Argentina's General Manager of Business Affairs, Kraft sought to introduce evidence of actual customer confusion. . . . Bertran recounted his observations of customers in an Argentine supermarket choosing packages of both Philadelphia brand and Pennsylvania brand cream cheese, or choosing Pennsylvania brand and then returning to exchange it for Philadelphia brand. Bertran reported that one customer told him that he thought the two brands were different versions made by the same company. Another customer said that he had picked up the Pennsylvania packages by mistake because the two brands were on the same shelf and both had silver packaging. ${ }^{247}$

The court found "that Bertran's testimony about customers he observed and their statements to him [were] admissible under the state of mind exception to the hearsay rule." ${ }^{248}$ In support of this conclusion, the court cited precedent from across the country for the proposition that statements showing the declarant's then-existing state of mind are admissible as long as they are "relevant to the case." 449 The court then found that the subject statements were relevant to the case because "likelihood of customer confusion is a key element" in a trademark infringement action, rendering Bertran's testimony "admissible under the 803(3) exception because it [was] indicative of the customers' thenexisting confused state of mind.,250

Additionally, courts consistently have found that Rule 803(3) allows for the admission of statements by customers explaining why they ceased dealing with a business. For instance, in Celebrity Cruises Inc. v. Essef Corp., a cruise line brought an action against a whirlpool spa manufacturer after passengers contracted Legionnaires' Disease from the

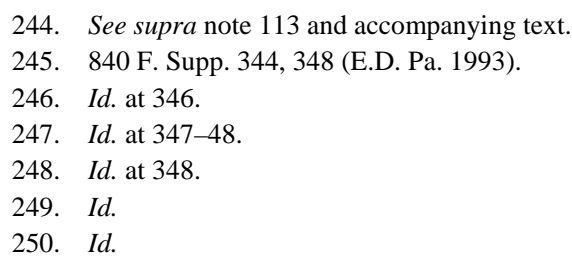


company's spa on the cruise line and successfully sued the cruise line for negligence. ${ }^{251}$ In this latter action, the cruise line sought damages for lost profits, and the cruise line tried to present testimony that customers indicated that they stopped buying tickets for the cruise line based upon the Legionnaires' Disease incident. ${ }^{252}$ The United States Southern District of New York allowed such testimony, citing several prior opinions for the proposition that "testimony concerning the motivation of customers for ceasing to deal with a business is admissible under the state of mind exception to the hearsay rule, Rule 803(3) of the Federal Rules of Evidence.",253

If statements by third-parties - customers - concerning their reasons for ceasing to deal with companies are admissible under Rule 803(3), then surely statements by parties — defendants — concerning their reasons for ceasing to deal with prosecutors are also admissible under the Rule. All that is required for a defendant to be able to present evidence that he rejected a favorable plea bargain despite the rule against hearsay is that his state of mind be "relevant to the case."254 As noted, United States $v$. Biaggi is "the leading case on the issue" of whether defendants can present evidence that they rejected offers of immunity. ${ }^{255}$ And in Biaggi, in reversing the defendant's conviction based upon the district court's exclusion of the defendant's rejection of such an offer, the Second Circuit relied upon the fact that "[w]here evidence of a defendant's innocent state of mind, critical to a fair adjudication of criminal charges, is excluded, we have not hesitated to order a new trial."256 In other words, evidence of a defendant's innocent state of mind is highly relevant to his defense.

The numerous circumstances in which courts allow evidence establishing defendants' consciousness of guilt further underscore the relevance of evidence of a defendant's state of mind. For instance, it is well established that evidence that a defendant fled from a police officer $^{257}$ or used false identification ${ }^{258}$ is relevant and admissible to show the defendant's consciousness of guilt. It is also well established

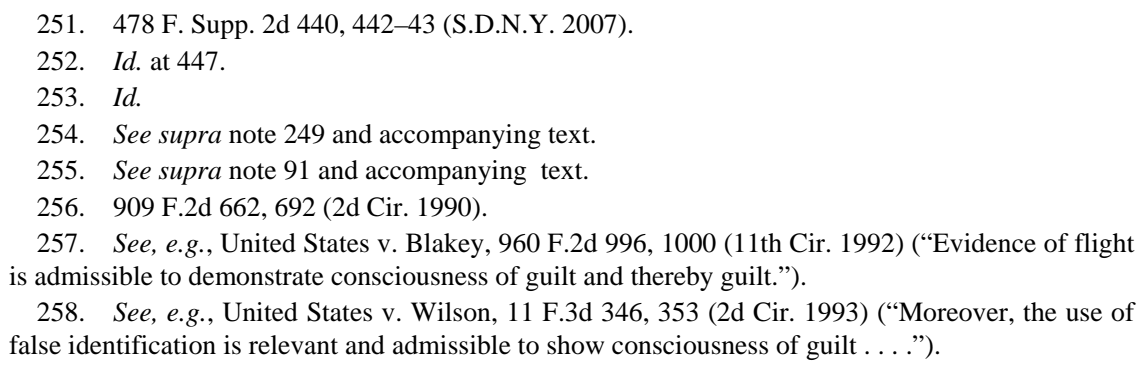


that "[e]vidence of a threat by a defendant respecting a specific adverse witness indicates that the defendant was conscious of the weakness of his case" and that "such evidence creates a compelling inference that the defendant's case lacks merit." 259

This latter point also explains why favorable plea offers by prosecutors are admissible under Rule 803(3): such an offer reveals that the prosecutor was conscious of the weakness of his case. ${ }^{260}$ And just as courts have recognized the relevance and admissibility of evidence relating to a defendant's state of mind, courts have recognized the relevance and admissibility of evidence relating to a prosecutor's state of mind. For example, courts have found that defendants can present evidence "relating to the delay in the commencement of the prosecution against them as an implied admission by conduct on the part of the State's witnesses that they were conscious of the weakness of the State's case against the defendants."261

\section{Rule 408 Should Not Bar Admission of Evidence of Rejected Plea Bargains}

As noted, while there is a split among courts, ${ }^{262}$ some courts hold that the rationale of Federal Rule of Evidence 408, which governs settlement negotiations between parties in civil cases, should be extended to criminal cases, meaning that "government proposals concerning pleas should be excludable." 263 Whatever the validity of this position before 2006, it is now clear that Rule 408 no longer provides a defensible rationale for excluding evidence that a defendant rejected a favorable plea bargain.

The civil negotiations most analogous to plea negotiations are civil negotiations between a private citizen and a government regulatory, investigative, or enforcement agency. Before 2006, "federal appellate courts were sharply divided over whether in criminal cases Rule 408 required the exclusion of statements made in compromise negotiations over civil claims."264 At this point, many courts found that Rule 408's exclusionary rationale applied to evidence that a defendant rejected a

\footnotetext{
259. United States v. Rocha, 916 F.2d 219, 241 (5th Cir. 1990).

260. See infra Part V.D.

261. State v. Black, 53 S.E.2d 443, 445 (N.C. 1949).

262. See supra note 61 and accompanying text.

263. United States v. Verdoorn, 528 F.2d 103, 107 (8th Cir. 1976).

264. Robert A. Weninger, Amended Federal Rule of Evidence 408: Trapping the Unwary, 26 REV. LiTIG. 401, 417 (2007).
} 
favorable plea bargain because "[m]eaningful dialogue between the parties would, as a practical matter, be impossible if either party had to assume the risk that plea offers would be admissible in evidence.”265

To the extent that these courts also held that Rule 408 required the exclusion in criminal cases of statements made in civil negotiations between a private citizen and a government regulatory, investigative, or enforcement agency, there was a certain symmetry to their approach. Rule 408 required such exclusion because otherwise meaningful dialogue and settlement between a private citizen and an agency would be practically impossible if the citizen had to assume the risk that his statements would be admissible against him in a subsequent criminal prosecution. Similarly, Rule 408's rationale required exclusion of evidence of a defendant's rejection of a favorable plea bargain because otherwise meaningful dialogue and plea agreement between a criminal defendant and the prosecution would be practically impossible if the prosecution had to assume the risk that its offer (and the defendant's rejection) would be admissible if the case proceeded to trial.

In 2006, however, Congress amended Rule 408. The Rule now deems inadmissible "conduct or statements made in compromise negotiations regarding [a] claim, except when offered in a criminal case and the negotiations related to a claim by a public office or agency in the exercise of regulatory, investigative, or enforcement authority."266 The accompanying Advisory Committee's Note indicates that "the amendment provides that Rule 408 does not prohibit the introduction in a criminal case of statements or conduct during compromise negotiations regarding a civil dispute by a government regulatory, investigative, or enforcement agency."267

As support for this conclusion, the Advisory Committee cited to the Seventh Circuit's opinion in United States v. Prewitt. ${ }^{268}$ In Prewitt, the Securities Division of the Indiana Secretary of State's Office began an investigation of Sterling American Financial Group, Inc. ${ }^{269}$ Sterling thereafter began settlement and compromise efforts with the Security Division, during which Security Division investigators twice interviewed

265. Verdoorn, 528 F.2d at 107.

266. FED. R. EVID. 408(a)(2) (emphasis added).

267. FED. R. EVID. 408 advisory committee's note.

268. Id. (citing United States v. Prewitt, 34 F.3d 436, 439 (7th Cir. 1994)).

269. Prewitt, 34 F.3d at 438. 
Jack V. Smillie, Sterling's founder. ${ }^{270}$ More than two years later, Smillie was indicted on five counts of mail fraud. ${ }^{271}$

After Smillie was convicted, his principal contention on appeal was that the district court violated Federal Rule of Evidence 408 by allowing the prosecution to present into evidence statements that he made to Securities Division investigators during compromise negotiations. ${ }^{272}$ The Seventh Circuit responded that " $[\mathrm{t}] \mathrm{he}$ clear reading of this rule suggests that it should apply only to civil proceedings, specifically the language concerning validity and amount of a claim.,273 It continued that "[n]othing in Rule 408 specifically prohibits the receipt of evidence in criminal proceedings concerning the admissions and statements made at a conference to settle claims of private parties." ${ }^{274}$ Thus, the court concluded that "Rule 408 should not be applied to criminal cases.",275 Moreover, the Seventh Circuit found that "Rule 11(e)(6) of the Federal Rules of Criminal Procedure [was] of no help to this defendant. It applies to the inadmissibility of pleas, plea discussions, and related statements in criminal cases." 276

After its citation to Prewitt, the Advisory Committee noted that "[w]here an individual makes a statement in the presence of government agents, its subsequent admission in a criminal case should not be unexpected." 277 The Committee further found that "[t]he individual can seek to protect against subsequent disclosure through negotiation and agreement with the civil regulator or an attorney for the government."278 The Committee then concluded by noting:

Statements made in compromise negotiations of a claim by a government agency may be excluded in criminal cases where the circumstances so warrant under Rule 403. For example, if an individual was unrepresented at the time the statement was made in a civil enforcement proceeding, its probative value in a subsequent criminal case may be minimal. But there is no absolute exclusion imposed by Rule 408.

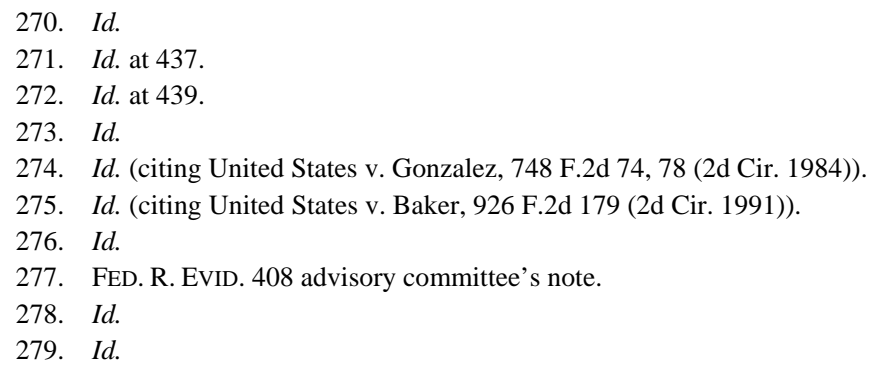


In other words, Congress found that meaningful dialogue and settlement between a private citizen and an agency is practically possible, despite the citizen having to assume the risk that his statements will be admissible against him in a subsequent criminal prosecution. Accordingly, it found that Rule 408 does not apply to the civil negotiations most analogous to plea negotiations. ${ }^{280}$ In effect, Congress used the same logic as Justice Thomas in Mezzanatto. As noted, in Mezzanatto, Justice Thomas rejected the argument that the plea-related Rules are nonwaiveable because "[a] sounder way to encourage settlement is to permit the interested parties to enter into knowing and voluntary negotiations without any arbitrary limits on their bargaining chips."281

In other words, according to Justice Thomas, while the plea-related Rules preclude prosecutors from admitting evidence of a defendant's statements made during plea discussions, prosecutors can force defendants to waive the protections of these rules. Meanwhile, according to Congress, while Rule 408 does not preclude prosecutors from admitting evidence of a defendant's statements made during civil negotiations between the defendant and an agency, defendants can negotiate with the civil regulator or an attorney for the government to have these statements deemed inadmissible. This was the same reasoning advocated by the defendant in Woodsum - while the plearelated Rules do not preclude defendants from admitting evidence that a defendant rejected a favorable plea bargain, prosecutors negotiate with the defendant to have these rejections deemed inadmissible. ${ }^{282}$ Based on Congress's incorporation of Justice Thomas's analysis in Mezzanatto into Rule 408, courts can no longer rely upon Rule 408 to preclude evidence that defendants rejected favorable plea bargains. Instead, as the Advisory Committee noted, Rule 403 should present the only possible bar against the introduction of such rejections. ${ }^{283}$

\section{Evidence that a Defendant Rejected a Favorable Plea Bargain Passes the Rule 403 Balancing Test}

As noted, some courts have found that evidence that a defendant rejected a favorable plea bargain is inadmissible because it fails the

\footnotetext{
280. See id.

281. United States v. Mezzanatto, 513 U.S. 196, 208 (1995).

282. See supra note 9 and accompanying text.

283. FED. R. EVID. 408 advisory committee's note.
} 
balancing test set forth in Federal Rule of Evidence $403,{ }^{284}$ which provides that "[a]lthough relevant, evidence may be excluded if its probative value is substantially outweighed by the danger of unfair prejudice, confusion of the issues, or misleading the jury, or by considerations of undue delay, waste of time, or needless presentation of cumulative evidence.”285 Conversely, as noted, most courts have adopted the reasoning of the Second Circuit in Biaggi and have found that evidence that a defendant rejected an offer of immunity is admissible and passes the Rule 403 balancing test. ${ }^{286}$ This Section argues that evidence of rejected plea bargains fares at least as well as evidence of rejected offers of immunity under the Rule 403 balancing test, meaning that courts should similarly deem this former type of evidence admissible.

First, evidence that a prosecutor offered a favorable plea bargain to a defendant has significant probative value for establishing the weakness of the prosecution's case. It is well established that "[t]he overwhelming majority of prosecutors view the strength or weakness of the state's case as the most important factor in the task of bargaining." 287 Indeed, "a number of studies have identified the strength of the evidence as one of the primary influences on prosecutors’ plea bargaining decisions." ${ }^{288}$ For instance,

[a] 1964 article cited with approval in the Advisory Committee Notes to the 1974 amendments reported that $85 \%$ of the prosecutors surveyed, representing 31 states, were influenced by weaknesses in the government's case; 60\% were influenced by the victims' preferences; $36.7 \%$ by their office's heavy workload; $31.7 \%$ by the fact that the penalties the defendant faced were too harsh; and $26.7 \%$ by sympathy for the defendant. ${ }^{289}$

In light of this data, evidence of a favorable plea offer by a prosecutor has significant probative value for establishing the weakness of the prosecution's case. While other factors may play a role in a

\footnotetext{
284. See supra notes $68-70$ and accompanying text.

285. FED. R. EVID. 403.

286. See supra notes $91-97$ and accompanying text.

287. Albert W. Alschuler, The Prosecutor's Role in Plea Bargaining, 36 U. CHI. L. REV. 50, 58 (1968); see also Russell D. Covey, Signaling and Plea Bargaining's Innocence Problem, 66 WASH. \& LEE L. REV. 73, 77 n.14 (2009) ("Given any initial charge carrying a standard sentence upon conviction, the primary pricing variable is the strength of the evidence in the case.”).

288. Margareth Etienne \& Jennifer K. Robbennolt, Apologies and Plea Bargaining, 91 MARQ. L. REV. 295, 318 (2007).

289. John Gleeson, The Sentencing Commission and Prosecutorial Discretion: The Role of the Courts in Policing Sentence Bargains, 36 HOFSTRA L. REV. 639, 642 n.10 (2008).
} 
prosecutor offering a favorable plea bargain to a defendant, the above data reveal that nearly every prosecutor is influenced by the weakness of the prosecution's case in making a plea offer. ${ }^{290}$ And "if we assume that prosecutors are motivated by a desire to avoid acquittals, they are likely to adjust their plea offers so as to create the largest differentials in cases where the government evidence is weakest." ${ }^{291}$ Put another way, "the more likely it is that a defendant will be acquitted, the more attractive the plea offer that he will receive. Thus, for example, defendants with colorable claims for evidentiary exclusions will be offered greater concessions than similarly situated defendants without such claims.,292

Indeed, some courts have acknowledged the probative value of such evidence while still deeming it inadmissible. In Woodsum, discussed in the Introduction to this Article, the defendant claimed that the trial court erred in excluding evidence that he rejected a favorable plea bargain because it was evidence of his innocent state of mind. ${ }^{293}$ The Supreme Court of New Hampshire, however, rejected his appeal, concluding that “[a]n 'extraordinarily beneficial' plea offer is especially likely to induce a defendant to risk a trial, regardless of his or her guilt or innocence, for the offer of a beneficial plea may indicate that there are problems with the State's case." 294 The court's former conclusion is debatable, ${ }^{295}$ but it seems clear that evidence of rejection of a favorable plea bargain has significant probative value for establishing the weakness of the prosecution's case.

Conversely, an offer of immunity has little probative value for establishing the weakness of the prosecution's case against the person being offered immunity. Prosecutors offer immunity "to preclude a witness's reliance on his fifth amendment [sic] privilege against compelled self-incrimination." ${ }^{, 296}$ And while there are no studies uncovering the reasons why prosecutors offer immunity, the Seventh Circuit in United States $v$. Palumbo noted that "[p]romises of immunity are important weapons in the fight against large-scale criminal enterprises; the government often snares big fish with information gained

\footnotetext{
290. See id.

291. Louis Michael Seidman, Factual Guilt and the Burger Court: An Examination of Continuity and Change in Criminal Procedure, 80 CoLUM. L. REV. 436, 476 (1980).

292. Nancy Amoury Combs, Copping a Plea to Genocide: The Plea Bargaining of International Crimes, 151 U. PA. L. REV. 1, 26 (2002).

293. See supra note 4 and accompanying text.

294. State v. Woodsum, 624 A.2d 1342, 1344 (N.H. 1993).

295. See infra notes $305-13$ and accompanying text.

296. United States v. Harvey, 869 F.2d 1439, 1445 (11th Cir. 1989).
} 
from little fish. In return, the little fish are granted immunity from prosecution based upon the information they provide to the government."297

Indeed, "[e]ffective prosecution of conspiracies often entails the investigative tactic known as 'ladder climbing': less culpable conspirators are immunized, often after being convicted themselves, in order to compel their testimony against more culpable coconspirators."298 Moreover, "[i]n cases in which the 'ladder climbing' tactic is frequently employed, such as corporate conspiracies and racketeering, the prosecution's evidence may consist almost entirely of testimony by those implicated in the crime."299

In other words, a prosecutor's offer of immunity is typically based upon the prosecution having a weak case against someone other than the person to whom they are offering immunity. The fact that a prosecutor offered an individual immunity thus says nothing about the strength of the prosecution's case against the offeree; it merely reveals that the prosecutor thinks that the offeree can incriminate someone more important but that the prosecutor fears that the offeree will refuse to do so unless offered immunity. Indeed, as noted above, it is not uncommon for prosecutors to offer immunity against those who have already been convicted of some crime. ${ }^{300}$

A prosecutor's offer of a favorable plea bargain thus clearly is more probative than a prosecutor's offer of immunity on the issue of the weakness of the prosecution's case. But is the inverse true with regard to how probative rejections of the two types of offers are on the issue of the defendant's innocent state of mind? Again, as noted, the Supreme Court of New Hampshire in Woodsum found that a defendant's rejection of a favorable plea offer is not especially indicative of his innocent state of mind because the offer reveals the weakness in the State's case and makes the defendant especially likely to risk trial. ${ }^{301}$ But is this actually true?

First, it seems safe to assume that "factually innocent defendants tend to have stronger cases than those who are guilty," meaning that it is "innocent defendants [who] typically receive especially attractive plea

\footnotetext{
297. 897 F.2d 245, 246 (7th Cir. 1990).

298. Comment, Defense Witness Immunity and the Right to a Fair Trial, 129 U. PA. L. REv. 377, 395-96 (1980).

299. Id. at 396.

300. See supra note 298 and accompanying text.

301. See supra note 13 and accompanying text.
} 
offers." $^{302}$ Thus, the mere existence of a favorable plea offer is some evidence of an innocent state of mind by the defendant. But is the Supreme Court of New Hampshire correct that defendants given such favorable offers are especially likely to risk trial?

It is well established that guilty defendants "as a class are unusually prone to risk taking" because "a criminal history suggests a preference for gambling, just as it suggests that the defendant fears punishment less than most people." 303 Conversely, "risk aversion is a much more plausible assumption where innocent defendants are concerned (especially those with relatively clean records)., ${ }^{\text {304 }}$ Therefore, "[c]ritics ... claim that plea bargaining coerces a significant percentage of innocent defendants to convict themselves in exchange for a certain, reduced penalty." 305

Understandably, a significant percentage of defendants choose to accept plea bargains because few defendants can afford to go to trial, many defendants cannot make bail and want to avoid prolonged pretrial detention, and continued court appearances can be "tedious, inconvenient, and sometimes humiliating." "306 Moreover, “"almost everyone, including defendants, believe[s] that [the trial penalty exists]." "307 The trial penalty is the penalty judges impose at sentencing "on those defendants with the temerity to go to trial."308

There is ample support for the existence of such a penalty as "several studies that attempt like-to-like comparisons do find quite substantial differences in the sentences imposed after jury trials relative to those imposed after guilty pleas." ${ }^{309}$ For example,

in one study of sentences imposed for different offense types in five states, researchers found "consistent support" for the hypothesis that jury trial cases are associated with harsher average sentences than

\footnotetext{
302. Combs, supra note 292, at 27.

303. Robert E. Scott \& William J. Stuntz, Plea Bargaining as Contract, 101 YALE L.J. 1909, 1943 (1992).

304. Id.

305. Combs, supra note 292, at 27 n.100.

306. Michael M. O’Hear, Plea Bargaining and Procedural Justice, 42 GA. L. REV. 407, 418-19 (2008).

307. Id. at 419 n.33 (quoting CANDACE MCCoy, Politics AND Plea BARgaining: Victims' RIGHTS IN CALIFORNIA 164 (1993)).

308. Id. at 419.

309. Id. at 419 n.33.
} 
guilty plea cases, including a finding of a $350 \%$ plea-trial differential in sentence length in heroin distribution cases in one state. ${ }^{310}$

And in another study, "researchers found that sentences following jury trials were 44.5 months longer than those following guilty pleas, after controlling for offense type, criminal justice status at time of arrest, prior record, attorney type, geographic location, pretrial status, age, race, and gender." 311 Other studies, however, do not reveal a trial penalty. ${ }^{312}$ But the key point is not whether there is in fact a trial penalty; the key point is that the majority of defendants believe there is a trial penalty, which "drives the perceived need to plead guilty."313

Thus, the Supreme Court of New Hampshire's assertion that defendants offered favorable plea bargains are especially likely to risk trial appears ill-founded. Instead, a prosecutor's offer of a favorable plea bargain is probative of the weakness of the prosecution's case, which, in turn, is probative of the defendant's innocent state of mind and his actual innocence. A significant percentage of innocent defendants still decide to accept such plea bargains for some of the reasons listed above, and those reasons explain why rejection of a favorable plea bargain is probative of a defendant's innocent state of mind. Of course, a prosecutor could have a weak case against a guilty defendant and offer a favorable plea bargain for this or other reasons to the guilty defendant, who might reject it based upon his relative lack of risk aversion. Nonetheless, the empirical evidence and reasonable inferences therefrom seem to suggest that the former scenario is much likelier than the latter, meaning that a favorable plea offer and a defendant's rejection of it has strong probative value on two fronts. And as the Second Circuit found in Biaggi, the fact "[t]hat the jury might not draw the inference urged by the defendant does not strip the evidence of probative force."314

As the Second Circuit also found in Biaggi, evidence that a defendant rejected an offer of immunity is strongly probative of the defendant's innocent state of mind. ${ }^{315}$ And according to the court, "[r]ejection of an offer to plead guilty to reduced charges could also

310. Id. (citing Nancy J. King et al., When Process Affects Punishment: Differences in Sentences After Guilty Plea, Bench Trial, and Jury Trial in Five Guidelines States, 105 CoLUM. L. REV. 959, 973, 975 (2005)).

311. Id. (citing Candace McCoy, Plea Bargaining as Coercion: The Trial Penalty and Plea Bargaining Reform, 50 CRIM. L.Q. 67, 88-90 (2005)).

312. Id.

313. Id

314. United States v. Biaggi, 909 F.2d 662, 690-91 (2d Cir. 1990).

315. See supra notes 78-81 and accompanying text. 
evidence an innocent state of mind, but the inference is not nearly so strong as rejection of an opportunity to preclude all exposure to a conviction and its consequences." ${ }^{\text {,16 }}$ In reality, however, immunity is rarely the "Get Out of Jail Free" card that the Second Circuit made it out to be.

Before 1970, "Congress authorized only one form of immunity called 'transactional' immunity."317 After being given transactional immunity, the witness could not "be prosecuted for any crimes relating to the compelled testimony."318 In 1970, however, "Congress replaced the transactional immunity statute with one authorizing 'use' or 'derivative use' immunity, a narrower form of immunity that protects witnesses from any prosecution that relies on the use of the compelled testimony or evidence derived from the testimony." 319 Under use or derivative use immunity, the government can prosecute the immunity grantee for any crimes relating to his compelled testimony, but "it has the burden to show by a preponderance of the evidence that it obtained the evidence used to file charges against the immunized party from sources wholly independent of the immunized testimony."320

Prosecutors can, of course, still offer transactional immunity, but, understandably, "prosecutors are more predisposed to offer use immunity." 321 Indeed, while the Second Circuit's opinion in Biaggi does not reveal what type of immunity Wedtech Chief Executive Officer Mariotta rejected, the court does indicate that four other Wedtech officials testified under grants of use immunity, ${ }^{322}$ so this was presumably what Mariotta was offered as well. What this means is not that these officials were given the opportunity to preclude all exposure to a conviction and its consequences. It merely means that any testimony they gave, and any evidence derived from that testimony, could not later be used to prosecute them. Therefore, rejection of an offer of immunity is a lot less probative of a defendant's innocent state of mind than the Second Circuit made it out to be.

\footnotetext{
316. Biaggi, 909 F.2d at 691.

317. John F. Decker, Legislating New Federalism: The Call for Grand Jury Reform in the States, 58 OKLA. L. REV. 341, 362 (2005).

318. Id.

319. Id.

320. Id. at 362-63.

321. Christine J. Saverda, Note, Accomplices in Federal Court: A Case for Increased Evidentiary Standards, 100 YALE L.J. 785, 789 n.27 (1990).

322. United States v. Biaggi, 909 F.2d 662, 670 (2d Cir. 1990).
} 
Of course, at the time that a prosecutor offers and the prospective witness rejects immunity, the prospective witness might not even be suspected of any criminal wrongdoing. As noted above, prosecutors offer immunity to those who they think can incriminate important criminals but who might refuse to do so unless offered immunity. ${ }^{323}$ Such an offeree might reject an offer of use immunity based upon the belief that he has less chance of being prosecuted by declining the offer than by accepting the offer and testifying. Recognizing this concern, some state courts have rejected use immunity and required transactional immunity because of the insufficient assurance that a prosecution permitted by use immunity " "will in fact be based upon actually independent evidence. ",324

Conversely, the Second Circuit seemingly overstated its case when it concluded that "[a] plea rejection might simply mean that the defendant prefers to take his chances on an acquittal by the jury, rather than accept the certainty of punishment after a guilty plea." ${ }^{325}$ The conviction from a defendant's guilty plea is punishment, but in many cases, that is the only punishment received by the defendant. In Woodsum, discussed in the Introduction to this Article, the defendant declined a plea bargain under which his jail time would have been deferred. ${ }^{326}$ In other cases, prosecutors offer defendants plea bargains under which they would receive no jail time at all. ${ }^{327}$ Moreover, prosecutors often offer plea bargains under which defendants can plead guilty in exchange for a sentence of time served. ${ }^{328}$ If such defendants, like many defendants, cannot afford bail, they trade the certainty of release for continued pretrial detention and the uncertainty of trial if they reject a plea bargain.

In finding that a defendant's rejection of an offer of immunity is probative of his innocent state of mind, the Second Circuit in Biaggi also acknowledged that "there may be reasons for rejecting the offer that are consistent with guilty knowledge, such as fear of reprisal from those who

323. See supra notes 296-99 and accompanying text.

324. Roderick R. Ingram, Note, A Clash of Fundamental Rights: Conflicts Between the Fifth and Sixth Amendments in Criminal Trials, 5 WM. \& MARY BILL RTS. J. 299, 305-06 (1996) (quoting 1 ChARles T. MCCORMICK ET AL., MCCORMICK ON EvidEnCE § 143 (John William Strong ed., 4th ed. 1992)).

325. Biaggi, 909 F.2d at 691.

326. See supra note 2 and accompanying text.

327. See Montré D. Carodine, Keeping It Real: Reforming the "Untried Conviction" Impeachment Rule, 69 MD. L. REV. 501, 538 (2010).

328. See Lawrence C. Marshall, Litigating in the Shadow of Innocence, 68 U. PITT. L. REV. 191, 197 n.25 (2006) (book review). 
would be inculpated." 329 In some cases in which a defendant rejects a plea bargain, this same concern applies. Prosecutors often offer defendants favorable plea bargains in exchange for information, testimony against other defendants, or both, and a defendant who rejects such a plea bargain could do so based upon the fear of reprisal. ${ }^{330}$ But in plenty of cases, prosecutors offer defendants favorable plea bargains solely in exchange for defendants' guilty pleas to lesser charges. ${ }^{331}$ In such a case, there is no reason to believe that fear of reprisal rather than an innocent state of mind is the reason for the defendant's rejection of a favorable plea bargain.

Of course, another string that a prosecutor can attach to an offer of immunity is that the offeree must engage in investigative assistance. For instance, in the previously mentioned Fifth Circuit opinion in Maloof, the defendant rejected an offer of immunity that would have required him to surreptitiously record conversations by other suspects. ${ }^{332}$ It is easy to see why the defendant would have rejected that offer independent of an alleged innocent state of mind, and yet the Fifth Circuit found that his rejection passed the Rule 403 balancing test. ${ }^{333}$ Again, prosecutors can offer plea bargains in exchange for such substantial assistance as well, but in many other cases, no such string is attached, making a defendant's rejection of such an offer relatively more probative.

Overall, then, it does not appear that evidence that a defendant rejected an immunity offer has significantly more probative value than evidence that a defendant rejected a favorable plea offer. Therefore, given the fact that evidence of a favorable plea offer has significantly more probative value for establishing the weakness of the prosecution's case than evidence of an offer of immunity, the overall probative value of these two types of evidence is at worst commensurate. Of course, a lot depends on the details of a given offer. If a defendant is charged with murder in the first degree and rejects an offer to plead guilty to murder in the second degree, the offer and rejection likely have little probative

329. Biaggi, 909 F.2d at 690

330. See, e.g., Nicole L. Phillips \& Stephen Smith, Reinterpreting the Ethical Duties of a Prosecutor: Y-STR as a Model Investigatory Tool, 22 GEO. J. LEGAL ETHICS 1073, 1084 (2009) (noting that making plea bargains in exchange for investigative assistance or testimony is part of the prosecutor's investigatory role).

331. See, e.g., Angela J. Davis, Prosecution and Race: The Power and Privilege of Discretion, 67 FORDHAM L. REv. 13, 24 (1998) ("The typical plea bargain arrangement involves an agreement by the prosecutor to dismiss the most serious charge or charges in exchange for the defendant's guilty plea to a less serious offense.”).

332. See supra note 93 and accompanying text.

333. See supra note 97 and accompanying text. 
value. But if that same defendant rejects an offer to plead guilty to voluntary manslaughter, the probative value of the offer and rejection increase substantially.

Assuming that the rejected plea bargain is sufficiently favorable to have at least moderate probative value, courts should only exclude such evidence under Rule 403 if that probative value is substantially outweighed by the dangers identified in the rule. As noted, courts have found that the dangers of admitting evidence that defendants rejected favorable plea bargains are the dangers of confusing and misleading the jury. ${ }^{334}$ As the Supreme Court of New Hampshire found in Woodsum, the admission of such evidence creates "the great likelihood that its admission will draw extraneous, misleading information into a criminal trial.... [And this] inevitably invites an exploration of such collateral matters as the prosecutor's reasons for making the offer... or the defendant's motives for rejecting it.",335

It is difficult to say what other collateral matters besides these two would need to be explored if courts allowed defendants to present evidence that they rejected favorable plea bargains. If such evidence were allowed, the defendant would testify that he rejected a favorable plea offer because he knew that he did not commit the crimes charged and wanted to prove his innocence at trial. The prosecution would then cross-examine the defendant and seek to prove that he had other reasons for rejecting the offer. For instance, if the offer was contingent on the defendant testifying against his alleged co-conspirators, the prosecutor could question the defendant about whether he rejected the offer because of fear of reprisal.

The prosecution would then presumably call someone for the government to explain why the favorable plea bargain was offered. In the above example, the government representative would explain that the deal was offered because they wanted the defendant to testify against those higher up in the criminal conspiracy. Defense counsel would then cross-examine the representative and seek to prove that the prosecutor had other reasons for making the offer. Defense counsel could, for example, question the representative about whether the favorable deal was offered based upon the weakness of the prosecution's case against the defendant.

Such evidence could be confusing and misleading to jurors because it could invite consideration of other cases and the mechanics of plea

334. See State v. Woodsum, 624 A.2d 1342, 1344 (N.H. 1993).

335. Id. 
bargaining rather than the actual evidence of the defendant's innocence or guilt. That said, courts consistently allow defendants to present other evidence regarding plea offers that invite jurors to consider such collateral matters. For instance, it is well established that defendants can impeach witnesses for the prosecution through evidence that those witnesses were offered plea bargains in exchange for their testimony. ${ }^{336}$ And prosecutors often respond to such impeachment by presenting evidence about the complete plea bargain, including "the application of the plea bargain to 'any case that [the witness] might be involved in.",337 Sometimes, the impeachment of prosecution witnesses regarding plea bargains can be quite extensive, with such impeachment spanning "fortytwo pages of the record" in the Eighth Circuit case, Willis v. United States. $^{338}$ If such interrogations are not too confusing or misleading to pass the Rule 403 balancing test, then surely evidence that the actual defendant in a case rejected a plea bargain can pass the test as well.

Moreover, evidence that a defendant rejected a plea offer is no more confusing or misleading than evidence that a defendant rejected an immunity offer, and courts have consistently found that evidence of such a latter rejection passes the Rule 403 balancing test. ${ }^{339}$ Furthermore, as noted, prosecutors often offer plea bargains to defendants solely in exchange for their guilty pleas to lesser charges while prosecutors always offer immunity to procure the offeree's testimony against some other defendant. $^{340}$ In cases in which a defendant rejects a plea bargain offered solely in exchange for his guilty plea, evidence of his rejection is substantially less confusing and misleading than evidence that a defendant rejected an offer of immunity because the evidence would solely relate to the defendant's case. In sum, evidence that a defendant rejected a favorable plea bargain is no more, and possibly less, confusing and misleading than evidence that a defendant rejected an offer of immunity, meaning that the former type of evidence should also pass the Rule 403 balancing test.

\footnotetext{
336. See, e.g., Briley v. Bass, 742 F.2d 155, 160 (4th Cir. 1984).

337. Id. at 158 (alteration in original).

338. 87 F.3d 1004, 1006 (8th Cir. 1996).

339. See supra notes $91-97$ and accompanying text.

340. See supra note 331 and accompanying text.
} 


\section{CONCLUSION}

Federal Rule of Evidence 410 deems inadmissible statements made during plea discussions when offered "against the defendant who made the plea or was a participant in plea discussions." ${ }^{341}$ In amending this Rule in 1979, Congress made clear the purpose of the rule: to protect criminal defendants in the plea bargaining process. ${ }^{342}$ According to Congress, under the Rule, a defendant can present exculpatory statements made during plea discussions, and only after he has done so can the opposing party present incriminatory statements made by the defendant during such discussions. ${ }^{343}$

This Article makes clear that courts have not honored either aspect of this congressional intent. On the one hand, courts categorically have prevented defendants from presenting evidence that they rejected favorable plea bargains. ${ }^{344}$ On the other, courts consistently have thrown Mezzanatto's caution to the wind and allowed prosecutors to force defendants to waive the protections of the plea-related Rules to get to the plea bargaining table and allowed them to use defendants' incriminatory statements during plea discussions as substantive evidence of their guilt. $^{345}$ These courts may be right that nothing in the plain language of Rule 410 prevents defendants from waiving its protections, but it is equally clear that nothing in the Rule's text precludes defendants from presenting evidence that they rejected favorable plea bargains. And because no other rule of evidence prohibits the admission of evidence that a defendant rejected a favorable plea bargain, courts cannot continue to deem evidence of rejected plea bargains inadmissible.

\footnotetext{
341. FED. R. EVID. 410.

342. See supra notes $41-51$ and accompanying text.

343. See supra notes $42-51$ and accompanying text.

344. See supra Part III.

345. See supra Part IV.B.
} 